\section{EL MONTO ESTIMADO POR LOS ACTORES NO MARCA EL LÍMITE DE LA PRETENSIÓN*}

\author{
THE ESTIMATED AMOUNT BY ACTORS DOES \\ NOT MARK THE LIMIT OF THE PRETENSION
}

\author{
O VALOR ECONÔMICO ESTIMADO PELOS \\ ATORES NÃO MARCA 0 LIMITE DA \\ PRETENSÃO
}

\section{RESUMEN}

Luego de superar los obstáculos en su implementación en Colombia el Código General del Proceso, CGP, expedido mediante la Ley 1564 de 2012, entró a regir íntegramente desde el $1^{\circ}$ de enero del año 2016 de conformidad con el Acuerdo No. PSAA15-10392 del 1 de octubre del 2015, expedido por la Sala Administrativa del Consejo Superior de la Judicatura, vigente para toda la justicia ordinaria.

Como toda nueva legislación genera expectativas y temores que se van decantando con el transcurrir del tiempo desempeñando un papel importante las decisiones judiciales que los litigantes aceptan o las controvierten en las diferentes instancias, generando jurisprudencia que es examinada por los estudiosos y apasionados del derecho. En el presente escrito se analiza el Juramento Estimatorio de las pretensiones económicas junto al principio de congruencia en la indemnización de perjuicios, planteando la posición consistente en que "el monto estimado por los actores no marca el límite de la pretensión sino la medida del daño", sustentada con doctrina apoyada con la reciente jurisprudencia.

* Artículo de investigación independiente del autor

a. Docente de la maestría de Derecho en la Universidad de Medellín, conferencista, perito experto, arbitro en equidad, autor de Derecho de Daños, obra de tres tomos publicada por la editorial Leyer, actualmente director de Derecho de Daños Colombia.
Jorge Pantoja Bravo ${ }^{a}$ jorpan2@yahoo.com Fecha de recepción: 06 de febrero de 2016 Fecha de revisión: 09 de febrero de 2016 Fecha de aceptación: 21 de abril de 2017
MISIÓN JURÍDICA

Revista de Derecho y Ciencias Sociales Bogotá, D.C. (Colombia) Colaboradores Externos Nacionales Núm. 13 Año 2017

Julio - Diciembre, pp. 305 - 332

ISSN 1794-600X 


\section{PALABRAS CLAVE}

Daño, juramento estimatorio, principio de congruencia, incongruencia objetiva, reparación integral, indemnidad de las víctimas, principio de equidad, infra petita, extra petita, plus petita, vertebración del daño.

\section{ABSTRACT}

After overcoming obstacles in its implementation in Colombia, the General Code of Process, CGP, issued by Law 1564 of 2012, became fully effective on January 1, 2016 in accordance with Agreement No. PSAA15-10392 Of October 1, 2015, issued by the Administrative Chamber of the Superior Council of Judiciary, in force for all ordinary justice.

As all new legislation generates expectations and fears that are decanted over time playing an important role in the judicial decisions that the litigants accept or controvert in the different instances such as cassation, generating jurisprudence that is examined by scholars and those passionate about law; the situation that is analyzed in the present writing regarding the stimatory oath* of the economic claims along with the principle of consistency in the request of compensation for damages, stating the position that "the amount estimated by the actors does not mark the limit of the claim but the measure of the damage", sustained by doctrine and supported by recent jurisprudence.

\section{KEY WORDS}

Damage, estimatory oath, principle of congruence, objective incongruity, integral reparation, indemnity of the victims, principle of equity, infra petita, extra petita, plus petita, $\mathrm{v}$ ertebration of the damage**

\section{RESUMO}

Depois de superar os obstáculos na sua implementação na Colômbia, o Código Geral do

\footnotetext{
* Estimatory oath: The estimated amount of money in a special damages request, the amount of which is supported by reasonable evidence.

** Vertebration of the damage: It requires patrimonial damages and non-patrimonial damages to be calculated separately in, for example, a traffic accident.
}

Processo, CGP, emitido pela Lei 1564 de 2012, entrou em vigor a partir de 1을 de janeiro de 2016 de acordo com o Acordo no PSAA15-10392 do 1 de outubro de 2015, emitido pela Câmara Administrativa do Conselho Superior do Poder Judiciário, em vigor para todos os tribunais ordinários.

Como toda nova legislação gera expectativas e medos que são decantados com a passagem do tempo, desempenhando um papel importante as decisões judiciais que os litigantes aceitam ou controvérsem nas diferentes instâncias, gerando jurisprudência que é examinada pelos juristas. Este artigo analisa o Juramento afirmativo das reivindicações econômicas, juntamente com o princípio da consistência na compensação de danos, afirmando que "o valor econômico estimado pelos atores não marca o limite da reivindicação, mas a medida do dano" , apoiado pela doutrina e jurisprudência recente.

\section{PALAVRAS-CHAVE}

Dano, juramento afirmativo, princípio de congruência, inconsistência objetiva, reparação integral, indenização das vítimas, princípio da equidade, infra petita, extra petita, ultra petita, vertebração do dano.

\section{METODOLOGÍA}

En el desarrollo de la investigación se emplearon: el método histórico-jurídico en el estudio de la evolución de la figura jurídica del Juramento Estimatorio y su impacto en la decisión judicial, analizada con el método jurídico comparado para el examen de legislación anterior con especial hincapié en el principio de congruencia, la reparación integral, equidad e indemnidad de las víctimas; bajo el método hermenéutico para el estudio e interpretación de los fallos recientes contemplando dos casos relevantes.

\section{INTRODUCCIÓN}

Para comenzar se requiere revisar el arraigado concepto según el cual el juez debe condenar sobre lo pedido, siéndole vedado condenar más allá de lo pedido; relación que no debe ser absoluta dado que la única limitación que tiene el juez en orden a establecer el quantum de la indemnización es la medida del daño y nada más que el daño, conforme a los elementos de 
persuasión regular y oportunamente allegados al proceso. Basta con que se dé la racionalidad necesaria y una adecuación sustancial en donde la condena indemnizatoria está constituida solo por el monto que se pruebe, es decir, con lo probado en el proceso, ampliando el espectro dentro del cual el juzgador válidamente puede o debe moverse, hacia arriba o hacia abajo de esa cuantificación, sin caer, desde luego, en una resolución infra petita o plus petita.

Se presenta un caso de la jurisprudencia argentina del año 2015 en la cual el juez condena por 4,6 veces lo pretendido y dos casos nacionales que se analizan en extenso al final del presente escrito. El uno, trata de una demanda con una pretensión de 250 millones de pesos y en el transcurso del proceso se aportan dos dictámenes, uno de la parte que demanda y el otro de oficio, presentando una diferencia promedio con la pretensión de más de mil millones de pesos. En el otro caso la pretensión principal prospera, sin objeción o reparo alguno, pero el lucro cesante derivado de esta no se acepta, condenando al demandado por la sanción de Juramento Estimatorio y en costas.

Situación que nos lleva a analizar el principio de congruencia en la responsabilidad civil consagrado en el artículo 305 del Código de Procedimiento Civil que establece en su primer inciso: "La sentencia deberá estar en consonancia con los hechos y las pretensiones aducidos en la demanda y en las demás oportunidades que este Código contempla ..." (teniendo efectos la expresión "lo que se llegare a probar"), siendo viable condenar al demandado a pagar la suma pedida que, de ser mayor, aseguraba la eficacia jurídica las expresiones "o la que se pruebe", o "la que resultare probada", o "la que se probare en el proceso", o cualquiera otra expresión de similar contenido, sin quedar subordinado al monto que de manera expresa fuera indicado. Esto, considerando la jurisprudencia vigente en el Código de Procedimiento Civil según la cual no hay impedimento en condenar por una suma mayor dado que el monto determinado está subordinado a lo que se llegue a probar, sin tener el juez ninguna restricción legal para disponerla en la extensión real y efectivamente demostrada del daño causado. En se sentido es de tener en cuenta que tanto el artículo 305 del C.P.C. como el artículo 206 del C.G.P. vulneran de manera crasa el principio de indemnización integral del daño.
No obstante, el artículo 206 del CGP de manera taxativa en su inciso quinto, sobre la sanción al demandante, establece que el juez "no podrá reconocer suma superior a la indicada en el juramento estimatorio". Además, serán ineficaces de pleno derecho todas las expresiones que pretendan desvirtuar o dejar sin efecto la condición de suma máxima pretendida en relación con la suma indicada en el juramento. Sin embargo, este mismo código en el artículo 283 (opera en consonancia con el artículo 16 de la Ley 446 de 1998),en su inciso final, consagra: "En todo proceso jurisdiccional la valoración de daños atenderá los principios de reparación integral y equidad y observará los criterios técnicos actuariales". Es lo correcto privilegiar esta última disposición dado que la indemnización es integral, la víctima debe quedar en la posición más cercana antes de daño y, finalmente, ningún daño debe quedar sin resarcir; de tal manera que se pueda admitir, al contrario de lo que se desprende de esa tesis, que la única limitación que tiene el juez en orden a establecer el quantum de la condena está constituida solo por el monto que se pruebe y no por el monto estimado. Por lo tanto, conforme a los elementos de persuasión regular y oportunamente allegados al proceso, el juez tendrá la posibilidad de otorgar una suma superior, en aquellos casos que se lo permita el haber probatorio.

Es inconcebible e inaceptable que el agraviado no quisiese el resarcimiento íntegro, sino uno parcial o fragmentario, al respecto el doctor Enrique Gil Botero, manifiesta:

La reparación integral del daño como criterio exigido por el artículo 16 de la Ley 446 de 1998 plantea el problema de los fallos ultrapetita, es decir aquellos en que el juez encuentra en el proceso que la prueba de la naturaleza y la intensidad de los daños va más allá de la petición de la demanda formulada por el perjudicado o que no fue pedido separadamente ¿podría desconocer dicha realidad, y condenar sólo por lo pedido? No. Si ese fuera el sentido de la norma, no se hubiese necesitado siquiera de su consagración, el contenido sea tautológico y la norma sería un rey de burlas ${ }^{\mathbf{1}}$.

Esto es corroborado por la jurisprudencia de la Corte Suprema de Justicia:

1. GIL BOTERO, Enrique. Teoría de responsabilidad extracontractual del Estado, Medellín, Librería Jurídico Sánchez R. Ltda., 2001, $2^{a}$ ed., p. 39. 
Por el otro [lado], con el moderno principio de favor victimae, conforme al cual las dudas que puedan surgir a la hora de establecer la dimensión de la reparación han de resolverse en beneficio de quien injustamente sufrió el daño, por cuanto una definición contraria a la acabada de señalar restringiría, sin motivo racional alguno y en detrimento de aquel, sus posibilidades indemnizatorias -como ocurriría de aplicarse la postura objeto de esta rectificación-, al tiempo que supondría, aún contra las reglas de la experiencia y en contravía del postulado de la equidad pregonado en la Ley 446 de 1998, que el agraviado no quisiese el resarcimiento íntegro, sino uno parcial o fragmentario ${ }^{2}$.

Para conseguir la verdadera indemnidad de la víctima, revalidado por el mismo artículo 206 en el inciso primero, al exigir en la presentación de la demandan la denominada vertebración del daño se debe, en sus términos, " estimarlo razonadamente, (...) discriminando cada uno de sus conceptos" a indemnizar, además atribuyendo a cada uno un valor determinado. De parte del juez, el mismo código en el artículo 281, inciso primero, determina que "La sentencia deberá estar en consonancia con los hechos y las pretensiones aducidos en la demanda y en las demás oportunidades que este código contempla y con las excepciones que aparezcan probadas y hubieren sido alegadas si así lo exige la ley", según esto la pretensiones aducidas en la demanda lo son de manera indicativa y general, no como un límite inamovible.

No obstante, la norma del Juramento Estimatorio plasmada en el artículo 206 del CGP tiene su aspecto positivo al exigir la vertebración del daño o perjuicios discriminando cada uno de sus conceptos a indemnizar, evitando de esta manera una cifra global, por lo general exagerada, sin especificar qué la compone. Es la primera vez que en Colombia se exige la discriminación de los rubros indemnizatorios facilitando la ponderación por el juez, el cual a un daño similar asigna una condena muy disímil entre una y otra.

Se constata que, durante un largo período, las resoluciones judiciales, haciendo uso de una gran discrecionalidad (que, en muchos casos, constituía arbitrariedad) fijaban cuantías muy diferentes para compensar supuestos similares y

2. Corte Suprema de Justicia, Sala de Casación Civil, sentencia del 15 de abril de 2009, M.P. César Julio Valencia Copete. cantidades semejantes para compensar supuestos completamente diferentes, lo que comportaba un alejamiento del principio de igualdad (...), sometidos a los criterios personales de los jueces $\mathrm{y}$ magistrados que, haciendo uso de un poder discrecional, incurren en desigualdades inherentes a tal forma de valorar, sin que se entienda por qué una misma lesión corporal puede ser compensada de diferente manera ${ }^{3}$.

Además, tiene su aspecto negativo al sancionar al demandante que sobreestime sus pretensiones ya sea que estas presenten una diferencia del $50 \%$ con lo que llegase a probar o cuando determinado rubro indemnizatorio no se llegaré a probar, sin considerar ninguna sanción económica a la contraparte, es decir, demandados, terceros civilmente responsables y compañías aseguradoras; esto exclusivamente frente a los daños a las personas causados en su integridad, básicamente por lesiones personales y muerte.

En términos coloquiales se plantea que "la culpa es del que pide o del que otorga". Si creemos que la culpa es del que otorga entonces se debe disciplinar al juez, con el agravante de que no existen unos baremos (tal como sucede en España) o unas bases de datos confiables (como en Francia o Argentina). También consideramos que se debe sancionar no solo al que pide mucho sino al que hace ofrecimientos irrisorios, como lo hacen generalmente las aseguradoras, incrementado la religiosidad $\sin$ facultar la conciliación o el arreglo extraprocesal. Por lo tanto, el juez tendrá la posibilidad de otorgar una suma superior, en aquellos casos que se lo permita el haber probatorio.

En el presente estudio nos referimos exclusivamente a la incongruencia objetiva, es decir en los eventos en que se peca por exceso o por defecto en la condena de una indemnización: ultra, extra o mínima petita. Cabe señalar que el juez sólo indemnizará los daños debidamente probados y que resulten ciertos, no la mera posibilidad o hipótesis de daño, teniendo en cuenta que el monto estimado por los actores no marca el límite de la pretensión y conceder más de lo pedido no importando el principio de incongruencia por ultra petita, dado que el juez

3. HERRADOR GUARDIA, Mariano José. Director, Daño, responsabilidad y seguro, Ed. Francis Lefebvre, 11 de noviembre de 2016. p. 628 y 629. 
no está atado a los límites de la congruencia de su fallo, aspectos que se amplían a continuación.

\section{El juramento estimatorio no marca el límite de la pretensión, sino la entidad e intensidad del daño, siendo viable la condena ultra petita}

El caso emblemático lo tenemos en la jurisprudencia de argentina sobre la infección a una mujer titulado por la prensa argentina como: "Millonaria indemnizacion a una-mujer que, tras dar a luz, le amputaron sus miembros" en el cual se analiza en extenso en el presente escrito sobre la responsabilidad médica, nexo de causalidad, su reclamo, condena e indemnización, mediante sentencia del 7 de septiembre de 2015 del juez nacional en lo civil, Silvia Tanzi, donde los accionantes por daños y perjuicios estiman su cuantía en la suma de tres millones ochocientos cincuenta y ocho mil (\$3'858.000) pesos argentinos. En ampliación de la demanda formulan una nueva estimación de la cuantía del daño en la suma de ocho millones trescientos cincuenta y seis mil $\left(\$ 8^{\prime} 356.000\right)$ pesos argentinos, fallando ultra petita por la suma total de dieciocho millones setenta y seis mil novecientos ochenta (\$18'076.980) pesos argentinos, o sea 4,6 veces la pretensión inicial equivalentes a más de cuatro mil doscientos cincuenta millones de pesos colombianos, exactamente a $\$ 4.250^{\prime} 982.617$,oo (un peso argentino a $\$ 235,16$ de 1 de febrero de 2016),

Considero que este caso es lo más grave que le puede suceder a una mujer que tras un parto normal el día 9 de mayo de su cuarto hijo, se le practica una nueva intervención en la que le amputaron un brazo el día 22 de junio y previo consentimiento de la paciente, se amputaron los restantes miembros el día 26 de junio, es decir, en el trascurso de 47 días después del parto queda sin ninguna de sus extremidades y con un bebé de los mismos días bajo la situación de "amputar los cuatro miembros para salvarle la vida"; generado por una bacteria denominada estreptoco beta hemolítico del grupo A (EBHGA) que fue adquirida por esta mujer ${ }^{5}$.

4. La Capital. Millonaria indemnización a una mujer que tras dar a luz, le amputaron sus miembros. (En línea) Consultado el 01 de diciembre de 2016, En: http://www.lacapital.com.ar/ informacion-gral/millonaria-indemnizacion-una-mujer-quedar-luz-le-amputaron-sus-miembros-n468880.html

5. En el capítulo VI, "La Indemnización-Grandes Discapacitados" que se lo analiza en extenso, lo médico, la responsabilidad médica y del hospital, la indemnización analizada rubro por rubro entre lo
En términos sencillos es como si en Colombia la demandante pide 100 millones de pesos y el juez le concede 4,6 veces la pretensión inicial o sea 460 millones de pesos, en razón a que esta es la medida real del daño, de otorgarle solamente lo pedido simplemente sería una gran injusticia.

En otro escenario se infiere que para la Corte Suprema de Justicia tampoco constituye inconsonancia del fallo que se ordene una forma de reparación distinta de la solicitada en la demanda, toda vez que:

Según el principio dispositivo, el demandante en un proceso civil tiene derecho a establecer el límite de su pretensión y a reclamar que la reparación se haga de determinada manera; pero cuando el modo de resarcimiento que plantea es imposible de cumplir, o cuando resulta innecesario e inequitativamente oneroso, o cuando en criterio del juez no es el más adecuado para garantizar la indemnización plena, entonces nada obsta para que el funcionario judicial imponga la forma de reparación que estime más conveniente, sin que ello signifique que esté fallando extra o ultra petita ${ }^{6}$.

Que el juez se obligue de modo taxativo a aplicar una regulación que impide una reparación completa, donde la ley quedaba entronizada como principal y casi única fuente de los derechos, sería desconocer sus prescripciones, además de hacer prevalecer lo ritual por encima de la realidad concreta que se presenta ante ellos. Aunque solo pueda advertirla y comprenderla una vez reconstruida la totalidad del cuadro probatorio.

[...] la cantidad que señaló fue solo una pauta o guía susceptible de modificación, toda vez que de modo expreso manifestó que el pago de los gastos de recuperación debía hacerse 'por el tiempo que se requiera, según el concepto médico y que inicialmente estimamos en 24 meses'. En este punto conviene aclarar que la ausencia de petición expresa de ciertos rubros no es impedimento para que el juez los incluya en la sentencia, si en la demanda se reclama en forma generalizada la reparación integral de los daños, o si se emplean palabras o expresiones que

reclamado y lo concedido por el juez y su argumentación por cada rubro, en mi libro El Daño a la Salud, Leyer, 2016, p. 740 y sgtes.

6. C. Suprema de Justicia, Sala de Casación Penal, sentencia del 18 de diciembre de 2012, proceso 05266-31-03-001-200400172-01, M.P. Ariel Salazar Ramírez. 
estén inequívocamente dirigidas a obtener el pago de una indemnización plena ${ }^{7}$.

Además del principio de reparación integral del daño, de su indemnidad total, de regresar al estado antes del daño o lo más cercano a este, tenemos el axioma según el cual "se debe reparar el daño y nada más que el daño, ni más ni menos". La explicación que se da a esta regla se apoya en un principio general del derecho: si el daño se indemniza por encima del realmente causado, se produce un enriquecimiento sin causa a favor de la "víctima", si el daño se indemniza por debajo del realmente causado, se genera un empobrecimiento sin justa causa para la víctima. Por eso, en materia de indemnización del daño resarcible rigen los principios de la reparación integral y de equidad ${ }^{8}$. De otro lado está el aforismo según el cual "todo aquél que cause un daño injusto debe repararlo", tendencia a partir de la cual la doctrina ha venido a determinar qué daños son injustos, pues este es el filtro que se utiliza para establecer los daños resarcibles, entendiendo por injusto que no exista ningún derecho para causarlo y que la víctima, sin tener el deber de soportarlo, vea afectado un interés tutelado.

La no reparación del daño sufrido implicaría la ruptura del orden social y la aceptación de la posibilidad ilimitada de causar daño, siendo necesario reparar, resarcir o indemnizar. Por lo tanto, es elemental establecer qué es lo que será reparado, resarcido o indemnizado; es decir, si efectivamente hay daño.

Siendo viable y legal el fallo más allá de lo pedido, ultra petita, es viable, que con el Juramento Estimatorio del Código General de Procedimiento se hace indispensable que los abogados litigantes y para quienes pretendan el resarcimiento de los perjuicios de tipo patrimonial conozcan el tema de la liquidación y cuantificación de los perjuicios con su correcta aplicación, acorde a los principios indemnizatorios, junto con la jurisprudencia de las altas cortes. No obstante, la discrepancia de algunas de sus decisiones incluso en una misma corte (a una persona por la pérdida de su extremidad inferior derecha con una disminución del 95\% de la capacidad laboral le

\section{Ibídem}

8. “Artículo 16. Valoración de daños. Dentro de cualquier proceso que se surta ante la Administración de Justicia, la valoración de daños irrogados a las personas y a las cosas, atenderá los principios de reparación integral y equidad y observará los criterios técnicos actuariales". Ley 445 de 1998. asigna cuatrocientos (400) salarios mínimos legales mensuales vigentes por daño en la salud y a otra persona a consecuencia del hecho dañoso queda en estado parapléjico con una disminución del 100\% de la capacidad laboral le asigna doscientos (200) SMLMV por daño en la salud) ${ }^{9}$, sin desconocer su aporte; "escenario en donde la regulación legal no es suficiente al doctrinante le corresponde trazar esos caminos que la oriente"10.

Históricamente la jurisprudencia ha sido la encargada de concretar el alcance de la noción de daño y su tipología en cada momento histórico, de conformidad con los valores y principios en que se funda el sistema jurídico vigente y atendiendo al postulado de la reparación integral del perjuicio; lo que impide que se queden sin resarcimiento los bienes jurídicos tutelados por el ordenamiento constitucional y legal imperante. Ejemplo de ello es la consagración progresiva del daño moral, a la vida de relación y a los bienes jurídicos de rango constitucional como categorías autónomas de perjuicio indemnizable, los cuales fueron tenidos en cuenta por el sistema de la responsabilidad civil únicamente desde su incorporación por parte de la jurisprudencia, pues antes de dichas innovaciones simplemente no generaban la obligación de indemnizar.

En este punto cabe aclarar que para el derecho civil los preceptos constitucionales que tutelan bienes jurídicos particulares no son meros moldes arquetípicos o parámetros de interpretación, ni tan sólo principios que contienen mandatos de optimización que deben ser cumplidos en la medida de lo posible. Para el derecho civil, un derecho fundamental es un bien jurídico que goza de protección por el ordenamiento positivo, por lo que posee contenido sustancial y su quebranto apareja la consecuente indemnización de perjuicios en razón del postulado general de no causar daño a la persona o los bienes ajenos ${ }^{11}$.

9. Diferencia muy significativa transcrita en mi libro El daño a la salud, en el acápite "B. Inconveniencia del 'daño a la salud' como lo concibe el Consejo de Estado" de mayo de 2016, ed. Leyer, pág. 417 y sgtes, tomada de Derecho de Daños, tomo I, capítulo III Clasificación de los daños, numeral 4, pág. 74, y en el tomo II de Derecho de Daños "12. El 'daño a la salud' como lo concibe el Consejo de Estado, 2015, ed. Leyer," pág.34 sgtes., de mi autoría en donde se analiza en detalle.

10. GAVIRIA CARDONA, Alejandro, Manual de liquidación de perjuicios patrimoniales, ediciones Anaula, Junio de 2016. p. 5.

11. HERRADOR, Mariano. Op cit. p. 628 y 629. 
Por cuanto los bienes jurídicos protegidos por la Constitución y la ley son objeto de protección por el derecho civil, su vulneración apareja el consecuente resarcimiento en virtud del principio de reparación integral de los perjuicios; no hay ninguna razón para excluir del merecimiento indemnizatorio cuando a la pretensión sea menor a la entidad del daño:

no puede colmarse con una regulación sectorial sometida a un excepcional principio de reparación fraccional (...), pues no puede aplicarse un estatuto de reparación parcial a unos daños que están legalmente sometidos a la reparación integral, ..., dado que está fuera de toda duda razonable que la integridad reparatoria constituye el quicio del Derecho de la Responsabilidad Civil, tal como lo ha afirmado la jurisprudencia en consonancia con un criterio ultracentenario, reafirmado de continuo ${ }^{12}$.

Veamos si nuestro Código General del Proceso se encamina en dicho sendero respecto del Juramento Estimatorio, siendo una prueba de carácter obligatorio para quien pretenda el reconocimiento. Dentro de una demanda, del pago de una indemnización, compensación, mejora o fruto, requisito formal para la admisibilidad (Art. 82, CGP), su incumplimiento genera inadmisión (para que la subsane en el término de 5 días) y puede generar el rechazo (Art. 90, inc. 4, num 6 e inc.5, CGP). Si no se aportó el juramento estimatorio, la contraparte puede proponer esto como una excepción previa que implica nulidad de lo actuado o rechazo de la demanda, pues el artículo 206 determina que dicho juramento hará prueba de su monto mientras se hubiere presentado de manera idónea y su cuantía no sea objetada por la parte contraria dentro del traslado respectivo, de ser objetada faculta al juez a proferir un fallo superior a las pretensiones económicas y de otra parte, independiente de que se objete, debe sujetarse a lo probado, es decir, a la verdadera dimensión del daño.

\section{Eventos de no aplicación de la sanción por Juramento Estimatorio y el fallo ultra petita}

12. MEDINA CRESPO, Mariano, Conservación y progreso en el nuevo baremo de tráfico: gozos y sombras por lo que se resarce y deja de resarcir, En: HERRADOR GUARDIA Mariano José. Director, Daño, responsabilidad y seguro, Ed. Francis Lefebvre, 11 de noviembre de 2016, p. 259.
El juramento estimatorio es requisito de la demanda y a la vez una prueba de carácter obligatorio para quien pretenda el reconocimiento, dentro de una demanda, del pago de una indemnización, compensación, mejora o fruto. Por lo tanto, se reitera, de no prestar dicho juramento, según lo reglado en el CGP, el juez no podrá darle curso a la demanda.

Cuando se reclamen perjuicios el juramento no incluye los causados con posterioridad a la presentación de la demanda (inciso 6to, art. 206), $\mathrm{y}$ teniendo en cuenta que no se aplica a los daños extrapatrimoniales, en nuestro criterio los puede pedir y cuantificar en salarios mínimos mensuales legales vigentes en la presentación de la demanda. El Código General del Proceso, según algunas disposiciones aclaratorias con vigencia desde el momento de la promulgación del código (Art. 627), dispone de manera conclusiva que el juramento estimatorio es requisito de la demanda, contestación o petición correspondiente. Así resulta sin duda del contenido del art. 82 numeral 7, art. 90 numeral 6, art. 96 numeral 3, art. 283 y art. 284.

Las sanciones a demandantes previstas en el Código General del Proceso están en el parágrafo único del artículo 206, que regula el medio de prueba del juramento estimatorio, al pago de una sanción, en dos eventos: a) al prever una sanción equivalente al diez por ciento $(10 \%)$ de la diferencia entre el valor pretendido y lo probado; y b) del cinco por ciento (5\%) del valor pretendido, en el evento que se nieguen las pretensiones por falta de demostración de los perjuicios pero cuando sea imputable al actuar negligente o temerario de la parte, como requisito de procedencia de la sanción. Por esta razón los reclamantes deben evaluar cuidadosamente qué suma están en condiciones de probar.

En el evento de que el juzgador acepte algunas pretensiones pero niegue las demás, se podría inferir que no hay un actuar negligente, ni mucho menos temerario, dado que la pretensión prospera parcialmente, deviniendo inaplicable la sanción. En consecuencia aplicaría cuando se nieguen la totalidad de la pretensión en donde no se alcanzó por lo menos a demostrar uno de los rubros indemnizatorios, daño emergente y lucro cesantes básicamente, sin incluir los extrapatrimoniales en razón a que se tasan bajo la discrecionalidad del juez. 
Sin embargo, con relación a la sanción prevista en los casos en los que se nieguen las pretensiones por falta de demostración de los perjuicios, pese al obrar exento de culpa de la parte a la cual le correspondía hacerlo, la sanción se torna desproporcional, pues la falta de prueba puede deberse a la ocurrencia de alguna de las contingencias a las que están sometidos los medios de prueba, como, por ejemplo, la muerte del testigo o la pérdida o deterioro de documentos ${ }^{13}$.

Dicha sanción no aplica para los perjuicios extrapatrimoniales, "El juramento estimatorio no aplicará a la cuantificación de los daños extrapatrimoniales" (Art. 206, inc. 5, CGP), además cuando se reclame la indemnización de daños extrapatrimoniales se tendrán en cuenta para efectos de determinar la competencia por razón de la cuantía, los parámetros jurisprudenciales máximos al momento de la presentación de la demanda (Art. 25, inc. 6, CGP); la objeción habilita al demandante para pretender y probar una suma mayor, sin sanción alguna, de tal manera que quien objeta deberá analizar cuidadosamente su estrategia.

Cuando se objete dicha estimación el juez (Art. 206, inc. 5, CGP) puede fallar más allá de lo pedido. En nuestro criterio, lo mismo que cuando el juez dispone la estimación, si el demandado objeta la estimación con explicación de la inexactitud que le atribuye, el juramento estimatorio pierde eficacia como prueba y es necesario acudir a otras pruebas, facultando al juez a condenar por una suma superior a la estimada bajo juramento, sin aplicar sanción alguna al demandado dado que no consagró consecuencias adversas cuando el demandado objete y su objeción resulte infundada. De ser así, el demandante debe aportar o solicitar las pruebas para determinar el valor de los perjuicios (art. 206, inc. $2^{\circ}$ CGP), y si logra demostrar que el valor real es igual o superior a la estimación realizada en la demanda, el juez condenará al pago de la suma demostrada. Es decir, en la hipótesis expuesta, el juez podrá condenar a suma superior a la que se estimó siempre que las pruebas así lo demuestren, siendo una decisión ultra petita que se autoriza en el inciso final del artículo 283 del Código General del Proceso consagra: "En todo proceso jurisdiccional la valoración de daños atenderá los principios de reparación integral y equidad y observará los

13. QUINTERO PÉREZ, Magda Isabel, El juramento estimatorio en el Código General del Proceso, Legis on line, publicado el 04 de agosto del 2016. criterios técnicos actuariales", opera en consonancia con el artículo 16 de la Ley 446 de 1998.

\section{La sanción por Juramento Estimatorio}

La sanción por juramento estimatorio reglamentada en el inciso cuarto del artículo 206 del Código General del Proceso, adicionada en la Ley 1743 de 2014 por medio del artículo 13, modificando el juramento estimatorio, en adelante el inciso cuarto y el parágrafo del artículo 206 del Código General del Proceso, queda así:

Si la cantidad estimada excediere en el cincuenta por ciento (50\%) a la que resulte probada, se condenará a quien hizo el juramento estimatorio a pagar al Consejo Superior de la Judicatura, Dirección Ejecutiva de Administración Judicial, o quien haga sus veces, una suma equivalente al diez por ciento $(10 \%)$ de la diferencia entre la cantidad estimada y la probada.

\section{(...)}

Parágrafo. También habrá lugar a la condena a la que se refiere este artículo a favor del Consejo Superior de la Judicatura, Dirección Ejecutiva de Administración Judicial, o quien haga sus veces, en los eventos en que se nieguen las pretensiones por falta de demostración de los perjuicios. En este evento, la sanción equivaldrá al cinco por ciento (5\%) del valor pretendido en la demanda cuyas pretensiones fueron desestimadas.

Tenemos dos partes, la del inciso cuarto de sanción del 10\% cuando excede la pretensión y la del parágrafo del 5\%, cuando no se prueba la pretensión. Se analiza este último y después el inciso.

\section{a) Sanción del 5\%}

La aplicación de la sanción prevista en el parágrafo transcrito solo procederá cuando la causa de la falta de demostración de los perjuicios sea imputable al actuar negligente o temerario de la parte, esta condición es fijada por la Corte Constitucional mediante sentencia C-157 y C-332 de 2013 declarando la exequibilidad condicionada del parágrafo único del artículo 206 de la Ley 1564 del 2012, CGP, bajo el entendido que tal sanción -por falta de demostración de los perjuicios que conduce a la negación de las pretensiones- "no procede cuando la causa de la misma sea imputable a hechos o motivos ajenos 
a la voluntad de la parte, ocurridos a pesar de su obrar diligente y esmerado"14, afortunadamente esta condición se convierte en norma mediante la Ley 1743 de 26 de diciembre de 2014 (sobre nuevos recursos para mejorar el funcionamiento de la administración de justicia).

Esta ley además reglamenta el juramento estimatorio en dos aspectos: el primero, relacionado con el destinatario de las condenas impuestas, en vez del demandado como estaba en la ley inicialmente, al Consejo Superior de la Judicatura como consecuencia de la sobrestimación del valor de las pretensiones; consideramos que su destino debería ser a un fondo común para las víctimas tal como está reglamentado en Francia (Ley Badinter). El segundo, este muy importante, consiste en introducir en el texto legal, como condición para la procedencia de la sanción, la actuación negligente y temeraria de la parte que formuló el juramento, sin definir qué puede considerarse como actuación negligente y temeraria, dejando al juez de manera discrecional definir qué situaciones o circunstancias cumplen esta condición para proceder a la sanción del 5\% de lo no probado.

En consecuencia lo que se sanciona es "por la falta de demostración de los perjuicios, no por su sobrestimación", o sea, por la inexistencia del daño, porque el hecho dañoso es inventado siendo racionalmente imposible demostrarlo; mas no por pretender una indemnización exagerada, y dentro de ella la solicitud de los diferentes rubros indemnizatorios para su reconocimiento, valoración y cuantificación por el juez. Para este último parámetro las condenas en abstracto están prohibidas, por lo cual al juez le es permitido acudir al criterio de "equidad". Sobre los rubros indemnizatorios se pueden solicitar todos los habidos y por haber, retomando el caso de fallecimiento de un ser querido además del daño emergente, lucro cesante y daño moral, es viable solicitar el daño a la vida de relación, al proyecto de vida, "Daño a la salud" como lo denomina últimamente el Consejo de Estado, daño sexual, daño sicológico y/o siquiátrico, "desequilibro emocional", etc., etc., etc., sin que -en nuestro concepto- haya temeridad, la cual es inexistente dado que su ponderación es responsabilidad del juez, quien los aprueba o rechaza si estos rubros no están soportados siendo simples afirmaciones

14. Corte Constitucional. Sentencia C-157 de 2013. sueltas, pero bajo ningún sentido constituyen temeridad, esta temeridad se genera por el daño inexistente mas no por su sobrestimación en su cuantificación y/o en la solicitud de rubros indemnizatorios, aspectos que el juez debe ponderar, siendo por ello inaplicable la sanción del $10 \%$ que se analiza a continuación.

\section{b) Sanción del 10\%}

El inciso tercero del artículo 206 del Código General del Proceso establece que "Si la cantidad estimada excediere en el cincuenta por ciento $(50 \%)$ a la que resulte probada, se condenará a quien hizo el juramento estimatorio (...)" (negrilla fuera de texto).

La norma es clara, procede la sanción cuando exceda la cantidad estimada en el cincuenta (50\%) a la que resulte probada, por lo tanto no aplica cuando la cantidad estimada o reclamada sea deficitaria, menor - como en el caso mencionado de la jurisprudencia de Argentina donde el juez condena por 4,6 veces la pretensión inicial -, deviene inaplicable la sanción; argumento que refuerza nuestra tesis: el juramento estimatorio no marca el límite de la pretensión sino la entidad e intensidad del daño, siendo viable que el juez condene ultra petita y a la vez de gran utilidad para los litigantes de responsabilidad civil que estiman su pretensión muy por lo bajo o que, en términos comunes "se queden cortos". Por ejemplo, la demandante estima su pretensión en 250 millones de pesos pero el dictamen de parte $y$ del dictamen de oficio lo tasan en un mayor valor con un diferencia promedio de más de mil millones de pesos, sentenciando por el valor estimado en su pretensión o sea la suma 250 millones (ver Caso: Privilegia lo estimado de la pretensión y no el valor probado ostensiblemente mayor) demostrándose en el proceso una suma realmente mayor, so pretexto de lo estimado en demanda, o aún más grave que a la víctima no se le indemnicen los rubros a que tiene derecho, con la consecuencia de un enriquecimiento sin causa a su victimario o responsable civil del daño.

Entonces esta sanción se aplicaría cuando el litigante exagera su pretensión en relación a que lo probado resulte menor y esta diferencia supere el 50\%. Consideramos que esta diferencia no debe ser de manera global sino por cada rubro indemnizatorio de manera individual dado que el Art. 206 del CGP exige una discriminación de los 
daños y perjuicios ${ }^{15}$, resultado, una sanción menor. De otra parte, se deben excluir para el cálculo de la sanción los rubros indemnizatorios con su monto que se solicitaron pero se negaron por falta de demostración de los perjuicios (con una sanción del 10 y $5 \%$ respectivamente). Por ejemplo se solicitan 100 millones por daño estético que se niegan por falta de demostración en el entendido que el daño existe faltando su demostración dado que lo no existe no se puede demostrar. Salvo que el litigante se haya inventado el daño (el perjuicio), este es inexistente. Además resulta desquiciado reclamar algo inexistente lo que sería -tal vez- la única razón para no poder demostrarlo. Situación muy diferente a que el daño existe pero no se logró probarlo o su cuantificación económica no se hizo, en tal evento el juez debe aplicar el principio de equidad incorporado normativamente en el CGP en el artículo en el artículo 283 inciso final consagra: "En todo proceso jurisdiccional la valoración de daños atenderá los principios de reparación integral y equidad y observará los criterios técnicos actuariales", tomado de manera íntegra de la Ley 446 de 1998 en su artículo 16 en donde la misma jurisprudencia nacional precisa: "es posible acudir a la equidad para determinar el monto del daño, en aquellos casos límite, en que, habiéndose acreditado el perjuicio patrimonial, la determinación de su cuantía se torna extremadamente difícil, no obstante el cumplimiento de las cargas probatorias por la parte demandante"16.

\section{Lo que sucede en otros lares}

En posición del autor ${ }^{17}$, se debe sancionar no al que solicite una pretensión alta o "sobrestimada" si su pretensión no prospera, sino a la parte responsable obligada a su pago como es el tercero civilmente responsable y la aseguradora, en especial la aseguradora, cuando hace ofrecimientos irrisorios, presionado que pagará cuando exista condena judicial, es decir que lo hará cuando en el proceso penal la sentencia esté en firme para dar vía al incidente de reparación

15. Art. 206. "Quien pretenda el reconocimiento de una indemnización, compensación o el pago de frutos o mejoras, deberá estimarlo razonadamente bajo juramento en la demanda o petición correspondiente, discriminando cada uno de sus conceptos".

16. C. Suprema de Justicia, Sala de Casación Civil, sentencia de 28 de febrero de 2013, M.P. Arturo Solarte Rodríguez, exp. 110013103-004-2002-01011-01.

17. PANTOJA BRAVO, Jorge. Derecho de Daños, Tomo I, II y III, Leyer, 2015 integral. De esta manera se burla la acción directa de la víctima contra la aseguradora consagrada mediante la Ley 45 de 1990, que introdujo varias e importantes enmiendas al régimen del seguro de responsabilidad civil, estipulado en los artículos 1127 a 1133 de la codificación mercantil, con el propósito de otorgar una tutela eficaz a las personas lesionadas con la culpa del asegurado, a quienes dotó de instrumentos para obtener, de manera efectiva, la reparación del perjuicio recibido, que para su eficacia debe demandar civilmente ante la justicia ordinaria.

Sobre la sanción pecuniaria que debería ser solo aplicable a la parte obligada a su pago en responsabilidad civil como está legislado en Francia con la Ley Badinter (ley francesa 85-677 del 5 de julio de 1985), vigente a la fecha, que corresponde a un porcentaje del monto establecido en la base de datos AGIRA, Association pour la Gestion des Informations sur le Risque Automobile, además de obligar a su pago le quita el recurso de la segunda instancia, para de esta manera conminarlos a pagar indemnizaciones justas o por lo menos cercanas a la establecida en la base de datos, así:

[...] En el caso de una oferta insuficiente, la ley prevé18; si el juez al fijar en definitiva la indemnización, estima que la oferta propuesta por el asegurador era manifiestamente insuficiente, condenará de oficio al asegurador a entregar al fondo de garantía una suma a lo sumo igual al 15\% de la indemnización concedida, sin perjuicio de los daños e intereses que en el caso se hayan infligido a la víctima. Situación que incentiva la transacción o conciliación extraprocesal de montos justos y descongestionando la justicia al evitar la fijación por vía judicial de la indemnización que es demorada ${ }^{19}$.

Otra medida sería obligarlas a entregar a las víctimas un anticipo, generando el saldo de la indemnización un interés moratorio, tal como estaba legislado en España, ahora mediante la oferta de indemnización establecida mediante la Ley 35 del 22 de septiembre de 2015 de reforma

18. Ley francesa 85-677 del 5 de julio de 1985 conocida como Ley BADINTER, articula 17 „Si le juge qui fixe l'indemnité estime que l'offre proposée par l'assureur était manifestement insuffisante, il condamne d'office l'assureur à verser au fonds de garantie prévu par l'article L. 421-1 du code des assurances une somme au plus égale à 15\% de l'indemnité allouée, sans préjudice des dommages et intérêts dus de ce fait à la victime».

19. PANTOJA BRAVO, Jorge. Derecho de Daños, tomo I, ed. Leyer 2015, p. 78 
a la ley de Responsabilidad Civil y Seguro en la Circulación de Vehículos a Motor. Cabe observar en especial el artículo 7, que generaliza el sistema de oferta de indemnización o respuesta motivada; siendo su objetivo principal el de conseguir un resarcimiento justo, intentando restituir a la víctima a una situación lo más parecida posible a la gozada con anterioridad al accidente. Con ello quedan identificados nuevos perjudicados, se produce aumento de las indemnizaciones prestando especial atención a los casos de fallecimiento, incluyendo de igual manera nuevos conceptos resarcitorios como gasto médico futuro, lucro cesante, daños morales etc. Por ello el sistema de valoración va a apoyarse en los siguientes pilares: Principio de vertebración que vela porque se valoren por separado los daños patrimoniales y los no patrimoniales, y dentro de éstos aquellos conceptos perjudiciales.

Esta ley consagra además el Principio de reparación integral ${ }^{20}$ que permite incrementar la protección a las víctimas mediante la garantía de una indemnización suficiente, lo que sitúa a España a la altura de las reformas que en el ámbito comunitario se han emprendido en relación con el seguro del automóvil. Esta reforma se hacía necesaria no solo como intento de armonizar la responsabilidad civil a la del resto de la Unión Europea, sino en aras de conseguir una interpretación uniforme de las reglas del sistema español, velando porque a situaciones de hecho idénticas se le apliquen respuestas similares, evitando de este modo las incertidumbres a las que se venían sometiendo los perjudicados frente a las entidades aseguradoras. Cabe destacar que el nuevo baremo no solo se aplica en el ámbito de los accidentes de tráfico, sino que la jurisprudencia también lo viene aplicando como criterio orientativo para aquellos supuestos en los que medie una mala praxis médica o a los daños sufridos por un accidente laboral, entre otros.

20. La Ley 35 del 22 de septiembre de 2015 proclama los principios fundamentales del sistema de valoración en el Art. 33.1 y 2 :

"1. La reparación íntegra del daño y su reparación vertebrada constituyen los dos principios fundamentales del sistema para la objetivación de su valoración.

2. El principio de la reparación íntegra tiene por finalidad asegurar la total indemnidad de los daños y perjuicios padecidos. Las indemnizaciones de este sistema tienen en cuenta cualesquiera circunstancias personales, familiares, sociales y económicas de la víctima, incluidas las que afectan a la pérdida de ingresos y a la pérdida o disminución de la capacidad de obtener ganancias".

\section{La sanción no es la vía para desestimular la presentación de pretensiones sobrestimadas}

El argumento principal y único que argumenta la Corte Constitucional de la aplicación de sanciones únicamente a la parte demandante que sobreestime su pretensión o resulte no probada, es la de desestimular la presentación de pretensiones sobrestimadas(C-157 y C-332, 2013). Creemos que por vía sanción no se logra esta finalidad, por el contrario se genera un efecto perverso de indemnizar el daño parcialmente limitado a lo estimado en el juramento, quitándole totalmente la connotación al vocablo "estimado" que significa que la cifra jurada puede resultar mayor o menor, es una cifra estimada, no un valor fijo, único e inamovible puesto que el artículo 206 en el inciso 5 del CGP establece una prohibición perentoria: "El juez no podrá reconocer suma superior a la indicada en el juramento estimatorio".

Sobre la sanción al demandante la Corte Constitucional asevera que "es potencialmente adecuado para cumplir la finalidad de desestimular la presentación de pretensiones temerarias"21, conllevado a instaurar demandas reducidas y obligando a las víctimas a recibir una indemnización parcial. Esto a todas luces es injusto, repetimos que se debe sancionar no al que pida mucho sino al que hace ofrecimientos indemnizatorios irrisorios, como generalmente acostumbran las aseguradoras en su condición de tercero civilmente responsable. Sobre el papel de los seguros el doctor Mariano Medina Crespo es contundente:

[...] No han afectado a la sustancia del trágala normativo. Fenómeno consistente en que la norma ordena al asegurador que pague lo que él considera que debe pagar y que no pague lo que no quiere pagar; y ello mediante unos textos que, dictados por él, alcanzan el rango normativo (...), por la presencia del seguro porque el sector asegurador ambientó su conveniencia, gestionó su implantación y lo diseñó de acuerdo con sus cálculos financieros para incentivar su solvencia y garantizar sus rendimientos, ..., se decía que se trataba de evitar un plus resarcitorio, pero se quería el minus al que se rendía disimulada

21. Según el Comunicado № 13 de la Corte Constitucional de 21 de marzo de 2013. 
pleitesía (...). Se trataba de que esa cuantificación se acomodara al negocio del seguro para evitar las intervenciones y las quiebras que, por cierto, no causaron nunca los siniestros, antes bien, fueron otras actuaciones siniestras las que determinaron esas situaciones de insolvencia ${ }^{22}$. (Resaltado fuera de texto)

Afirmación que el Medina soporta en una sentencia del Tribunal Supremo de España, según la cual "el seguro se establece en función de la responsabilidad civil que ampara y no al revés". Con basde en esta el autor dice: "Como si lo recto fuera volver las cosas al revés; como si la lluvia cayera en función de los paraguas manejados; como si la lluvia de los daños tuviera que adaptarse a los paraguas del ingenio del asegurador"23.

El argumento "de evitar un plus resarcitorio", siendo infrecuente que se dé, se esgrime para justificar la sanción al demandante avalado por la Corte Constitucional, cuando asevera que la "finalidad de desestimular la presentación de pretensiones sobrestimadas o temerarias resulta acorde con el ordenamiento constitucional, toda vez que la norma demandada se refiere a las sanciones impuestas por la falta de demostración de los perjuicios"24. Esto en vez de contemplar la necesidad de disciplinar a los jueces que aceptan y condenan por "pretensiones sobrestimadas", con todo lo que ello implica, especialmente la inseguridad jurídica que se genera con la incerteza del monto a condenar, obstaculizando así el arreglo extraprocesal.

Resulta pernicioso que el juez se obligue de modo taxativo a aplicar una regulación que impide una reparación completa, donde la ley quedaba entronizada con principal y casi única fuente de los derechos. El derecho ha mutado hacia un nuevo concepto que amplía el concepto de norma, no solo para superar la identificación de ley con legalidad sino también para incluir

22. MEDINA CRESPO, Mariano, Conservación y progreso en el nuevo baremo de tráfico: gozos y sombras por lo que se resarce y deja de resarcir, en HERRADOR GUARDIA Mariano José. Director Daño, responsabilidad y seguro, Ed. Francis Lefebvre, 11 de noviembre de 2016, p. 252

23. MEDINA CRESPO, Mariano. Op. Cit. p. 253.

24. Corte Constitucional, Sentencia C-157, 2013. dentro de aquel a los principios ${ }^{25}$. Esto exige que la interpretación de la ley sea hecha teniendo en cuenta no solo sus finalidades sino también, entre otras cosas, los principios entendidos como mandatos que requieren que algo (por ejemplo, la indemnidad de la víctima y la correlativa obligación de indemnizarla, el principio de no causar daño, la rectitud y buena fe procesales, o la voluntad de buscar empeñosamente la verdad de los hechos) sea cumplido en la mayor medida posible; es más, en el juramento estimatorio los sujetos destinatarios son, ni más ni menos, los jueces, y sería desconocer sus prescripciones el hacer prevalecer lo ritual por encima de la realidad concreta que se presenta ante ellos, aunque solo pueda advertirla y comprenderla una vez reconstruida la totalidad del cuadro probatorio.

Los bienes o intereses protegidos por el derecho no están tipificados en todos los casos, pues la voluntad del legislador ha sido siempre -según una tradición que se remonta a los orígenes de la codificación- dejar abierta tal posibilidad para que sean los jueces quienes determinen en cada situación concreta qué eventos o consecuencias son dignos de ser considerados como daños resarcibles. Por ello los jueces de la República "detentan un poder discrecional de gran trascendencia, en cuanto a la valoración del merecimiento de tutela del interés vulnerado" ${ }^{26}$. Siendo viable y legal el fallo más allá de lo pedido, o sea una condena ultra petita, es viable. De otra parte, indudablemente una de las cuestiones más prácticas a la vez que trascendente en el seguro en general, pero, sobre todo, en el de responsabilidad civil en particular, es la reparación del daño al tercero que sufre contractual o extracontractualmente un perjuicio, un daño como consecuencia de un hecho ilícito, causado por el asegurado y que debe resarcir una deuda o indemnidad frente al mismo y que precisamente constituye el objeto del seguro de responsabilidad civil.

25. Al respecto ver el trabajo de William Jímenez Gil construye un mapa confiable de los pronunciamientos constitucionales, emitidos por la Corte Constitucional colombiana, y que "originalmente aparecían dentro del sistema jurídico colombiano como Principios Generales del Derecho Privado no escrito, pero incorporados como fuente final de cierre del sistema aplicado con base en la Ley 153 de 1887". JIMENEZ GIL, William. Entre reglas y principios. Revista Misión Jurídica, Vol. 1, No. 1, 2008, p. 15.

26. VISINTINI, Giovanna. ¿Qué es la responsabilidad civil? Bogotá: U. Externado de Colombia. 2015, p. 101. 
El quid estriba en qué ganamos todos con la trascendencia de una interpretación uniforme de las reglas del sistema, que dote de certidumbre al perjudicado y a las entidades aseguradoras respecto de la viabilidad de sus respectivas pretensiones, garantizando una respuesta igualitaria ante situaciones idénticas, y que contribuya decisivamente a la rápida solución judicial o extrajudicial de los conflictos.

Situación que nos lleva a estudiar el principio de congruencia en la responsabilidad civil y el artículo 206 del CGP para concluir que el monto estimado por los actores no marca el límite de la pretensión y conceder más de lo pedido no importa incongruencia por ultra petita, dado que es el daño el que fija el límite teniendo en cuenta el principio de reparación integral, principio consagrado en el mismo CGP en el artículo 283 inciso final: "En todo proceso jurisdiccional la valoración de daños atenderá los principios de reparación integral y equidad y observará los criterios técnicos actuariales"; es lo correcto, dado que la indemnización es integral, la víctima debe quedar en la posición más cercana antes de daño, ningún daño debe quedar sin resarcir; para conseguir la verdadera indemnidad de la víctima tiene que procederse a la denominada vertebración del daño como lo establece el mismo artículo 206 del CGP de incluir la totalidad de los daños y perjuicios a indemnizar, atribuyendo a cada uno un valor determinado en sus términos. "Deberá estimarlo razonadamente, ..., discriminando cada uno de sus conceptos" a indemnizar, atribuyendo a cada uno un valor determinado, exigencia del Código General del Proceso. Dicha estimación de la cuantía no se reduce a la simple enunciación de los valores que se consideran son los correspondientes a los perjuicios, sino que es necesario explicar de dónde resultan, "punto en el que se debe aplicar la teoría de los daños y de la estimación del perjuicio"27.

Al respecto, el siguiente análisis arroja luces sobre el tema:

El derecho de la víctima siempre debe ser indemnizada no es creación caprichosa o meramente producto de la razón humana, del voluntarismo. Un derecho injusto no es derecho

27. PINZÓN MUÑOZ, Carlos Enrique. "La reparación directa, aspectos procesales y probatorios", 3ra edición, Ibañez, 2016, p. 104. o lo es solo desde el punto de vista formal y no material; así como una sentencia injusta no es sentencia.

Dado que el responder no es un simple sancionar sino reconocer daños e indemnizarlos estableciendo la obligación de reparación del daño causado que comprende tanto el derivado de los actos ilícitos como igualmente de los lícitos, la responsabilidad puede definirse diciendo que es la obligación que pesa sobre una persona de indemnizar el daño sufrido por otra; en tal sentido, varios tratadistas, especialmente de derecho civil, al analizar el tema de la responsabilidad, comienzan sus estudios definiendo o expresando lo que se entiende por la noción de responsabilidad, y la mayoría de ellos concuerda en decir que es la obligación que tiene una persona que ha inferido daño a otra, de reparar dicho daño. ${ }^{28}$

Así, para Arturo Alessandri Rodríguez, "en derecho civil la expresión responsabilidad no se define por su fundamento que puede variar, sino por su resultado, es decir, por las consecuencias jurídicas que el hecho acarrea para el autor" ${ }^{29}$, en este sentido se dice que un individuo es responsable cuando está obligado a indemnizar el daño. Para los hermanos Mazeaud, "una persona es responsable civilmente cuando queda obligada a reparar un daño sufrido por otro" ${ }^{30}$; en tal sentido Planiol y Ripert expresan que "existe responsabilidad en todos los casos en que una persona queda obligada a reparar un daño sufrido por otra" ${ }^{31}$. Que aplica tanto en la responsabilidad Contractual y Extracontractual o Aquiliana, y sobre el deber general de no causar daño, exprese:

28. PANTOJA BRAVO, Jorge. Derecho de Daños, Tomo I, en el Capítulo I "De la responsabilidad clásica al Derecho de Daños", Leyer, 2015, p. 41 y 42.

29. ALESSANDRI RODRÍGUEZ, Arturo, De la responsabilidad extracontractual en el derecho civil, Santiago de Chile: Imprenta Universal, 1981, p. 10.

30. MAZEAUD, Henri; MAZEAUD, León, TUNC, André, "Tratado teórico y práctico de la responsabilidad civil", Buenos Aires, EJEA Argentina, Tomo I, volumen I, 1961, p. 7.

31. PLANIOL, Marcel y RIPERT, Georges. Tratado práctico de derecho civil francés, Tomo VI. Las obligaciones, Primera Parte, Habana, Ed. Cultural La Habana - Traducción española del Dr. Mario Diaz Cruz - Con el Concurso de René Savatier, 1946, p. 664. 
El deber general neminem laedere -no causar daño- es genérico; se aplica a las relaciones de los sujetos de derecho con independencia de que se hayan estipulado pautas de su conducta recíproca; es fundamento del orden jurídico y su violación genera responsabilidad como sanción. Por eso, el no causar daño a los demás es quizá, la más importante regla de las que gobiernan la convivencia humana. El principio general del derecho de no dañar al otro, hace que sea posible la vida en sociedad y que cuando es conculcado, acarrea una sanción que consiste en la obligación jurídica de indemnizar el daño causado.

El derecho no protege entonces a quien causa un daño a otro, sino que muy por el contrario hace nacer una obligación -en sentido jurídico- de dejar a esa persona en una situación lo más parecido posible a como se encontraba antes de sufrir el daño. Esto es lo que se llama "responder" o ser "responsable" o tener "responsabilidad" por el daño padecido por otra persona. La obligación de reparar el daño ha sido considerada como una sanción, más propiamente como una sanción resarcitoria, para diferenciarla de la sanción represiva propia del ámbito penal ${ }^{32}$

La palabra indemnización quiere decir que quien la percibe quede indemne y ello significa que abarca los perjuicios que se padezcan tanto en el orden material, en nuestros términos patrimonial, como en el moral (como categoría genérica, daños extrapatrimoniales), extendiéndose tanto al daño emergente como al lucro cesante; y, en concreto, en relación con la responsabilidad civil ex delito, señala que el espíritu de los preceptos que integran dicha regulación es claramente extensivo, pues el legislador quiere que los perjudicados sean resarcidos de forma cabal e íntegra, alcanzándose la total indemnidad. Lo anterior con independencia del orden jurisdiccional en que se hayan de establecer, siendo necesario siempre analizar el principio de congruencia.

\section{Ni el doble pago es legal, como tampoco lo es una indemnización reducida}

Para evitar la indemnización minorada o menguada y la indemnización que duplique el daño al superponer o repetir idénticas partidas, conviene acudir al principio de la reparación plena

\footnotetext{
$32 \quad$ Ibídem, p. 43 y 44
}

o integral del daño; más allá de dogmatismos o de rotulaciones reduccionistas se debe indemnizar todo el daño injusto padecido considerando conceptual y dinerariamente los distintos rubros que lo integran.

Rubros indemnizatorios que se deben probar $y$, de ser posible, cuantificar, para que el juez los identifique, diferencie, observe su identidad, alcance, evaluación concreta, los reconozca e indemnice. Lógicamente que no se pueden generar todos ellos, pero por lo general están presentes el daño emergente, el lucro cesante y el daño moral, por lo menos. La reparación del mismo debe efectuarse de manera integral, esto es procurando la mayor adecuación posible, en el caso concreto, entre el menoscabo y la indemnización.

Teniendo cuidado de caer en duplicaciones indemnizatorias, en excesos o demasías que transformen la reparación del juez en una fuente de lucro para el damnificado y de injustificado agravamiento de la situación del deudor, pero también por la mezquindad a la que desembocan en una indemnización escasa o insuficiente, desde que al ser menor a la debida no es el equivalente al daño sufrido, y por ende, no lo repara íntegramente, sufriendo un menoscabo en la esfera del damnificado. Tan solo la reparación jurídicamente plena o integral, que no es otra cosa que la indemnización o el equivalente dinerario en la medida de lo justo (equitativo) para el caso determinado.

El hecho de que las normas relativas a la responsabilidad civil extracontractual tengan una función indemnizatoria, obliga a distinguir -afirma Luis Díez Picazo- nítidamente Derecho de daños y Derecho de enriquecimiento. No pertenecen al primero, sino al segundo, la normas cuyo objeto es la reintegración o restitución de valores patrimoniales obtenidos mediante el ejercicio indebido de un derecho ajeno ${ }^{33}$.

El principio general es que el responsable debe resarcir todo el daño ocasionado con el acto ilícito, teniendo en cuenta que la finalidad de la indemnización es procurar restablecer, tan exactamente como sea posible, el equilibrio destruido por el hecho ilícito, para colocar así

33. DÍEZ PICAZO, Luis y DE LEÓN, Ponce, Derecho de Daños, Madrid, Civitas, S. A, 1999, p. 48. 
a la víctima en la misma o parecida situación patrimonial a la que se hubiese hallado si aquel no hubiese sucedido, bajo el lema de "se debe indemnizar el daño causado, todo el daño causado y nada más que el daño causado" pone de relieve la naturaleza cierta y exclusivamente resarcitoria de la acción de responsabilidad. Se trata, en definitiva, de indemnizar "todo" el daño causado pero no más. En la tarea de fijar el alcance y cuantía de la indemnización, lo que se procura es no trasponer o fugarse de la equidad y justicia, acotada, por un lado, por el principio de reparación integral y plena, y por otro, por el que impide lucrar con el daño sufrido, de manera tal que el perjudicado no quede ni más pobre ni más rico de lo que hubiera sido de no acaecer el evento dañoso.

Como regla, el daño debe medirse por lo que específicamente ha producido a quien lo ha padecido, "el resarcimiento entendido como la reparación que corresponde a la medida del daño'34; esto impone, consecuentemente, asegurar al responsable que su obligación no habrá de asumir un límite mayor del daño causado. Insistimos en que desde una perspectiva netamente resarcitoria, el hecho dañoso no debe convertirse en una fuente de enriquecimiento para la víctima y de correlativa expoliación para el dañador. Las reglas que regulan la extensión del resarcimiento, se orientan hacia esa finalidad, al menos en el plano de los principios universales. El clásico francés Ives Chartier expresa de manera general que conduce a la aplicación de cuatro reglas fundamentales: el daño debe ser fijado al momento de la decisión; la indemnización no debe ser inferior al perjuicio; la apreciación debe formularse en concreto y la reparación no debe ser superior al daño sufrido. $(1983,165)$

\section{Debe repararse el daño, todo el daño y nada más que el daño}

La responsabilidad civil, concebida lato sensu como la obligación de reparar, resarcir o indemnizar un daño causado injustamente, encuentra venero en la eterna búsqueda de la justicia, equidad y solidaridad para restablecer el equilibrio alterado con la conculcación de la esfera jurídica protegida por la norma.

34. DE CUPIS, Adriano. El daño, Ed. Bosch; España, 2ª edición, 1975, p. 753.
La consecuencia jurídica inmediata de que exista un daño resarcible, siempre que el mismo haya sido debidamente probado por la víctima, es la reparación correspondiente. En otros términos, la reparación es el fenómeno que se produce como reacción del derecho al hecho de que una persona le cause daño a otro, tal como lo prevén los artículos $2341^{35}$ y $2356^{36}$ del Código Civil estableciendo la obligación reparatoria "para el que ha cometido delito o culpa, que ha inferido daño a otro..." (Art. 2341) y que "...todo daño que pueda imputarse a malicia o negligencia de otra persona, debe ser reparado por ésta" (Art. 2356). Por su parte el artículo 1494 del Código Civil, dentro de las fuentes de la relación obligatoria, entre otras enuncia, el "hecho que ha inferido injuria o daño a otra persona, como en los delitos" y, en consecuencia, la obligación de repararlo. En el campo penal, el artículo 94 del Código Penal prescribe que "la conducta punible origina la obligación de reparar los daños materiales y morales causados con ocasión de aquélla", y los artículos 95 a 97 del mismo código hacen alusión a los daños patrimoniales (materiales) extrapatrimoniales (inmateriales), el artículo 96 establace "Los daños causados con la infracción deben ser reparados por los penalmente responsables, en forma solidaria, y por los que, conforme a la ley sustancial, están obligados a responder" y en el artículo 97 la tasación de los daños hasta mil (1000) salarios mínimos legales mensuales ${ }^{37}$.

Estas normas admiten en forma implícita que la valoración del perjuicio y su cuantificación deben efectuarse en el caso concreto, en función del interés conculcado y del perjuicio que deriva de

35. "Art. 2341. El que ha cometido un delito o culpa, que ha inferido daño a otro, es obligado a la indemnización, sin perjuicio de la pena principal que la ley imponga por la culpa o el delito cometido".

36. “Art. 2356. Por regla general todo daño que pueda imputarse a malicia o negligencia de otra persona, debe ser reparado por ésta. Son especialmente obligados a esta reparación: 1. El que dispara imprudentemente un arma de fuego. 2. El que remueve las losas de una acequia o cañería, o las descubre en calle o camino, sin las precauciones necesarias para que no caigan los que por allí transiten de día o de noche. 3. El que obligado a la construcción o reparación de un acueducto o fuente, que atraviesa un camino, lo tiene en estado de causar daño a los que transitan por el camino".

37. “Art. 97. Indemnización por daños. En relación con el daño derivado de la conducta punible el juez podrá señalar como indemnización, una suma equivalente, en moneda nacional, hasta mil (1000) salarios mínimos legales mensuales. Esta tasación se hará teniendo en cuenta factores como la naturaleza de la conducta y la magnitud del daño causado. Los daños materiales deben probarse en el proceso". 
tal situación, así como a los perjuicios colectivos. Diferenciando la responsabilidad civil de la penal; es así como el daño determina la medida de reparación bajo el principio de raigambre jurisprudencial que "se debe indemnizar el daño causado, todo el daño causado y nada más que el daño causado", que acude la doctrina francesa, en el sentido de que debe repararse el daño, todo el daño y nada más que el daño (le dommage, tout le dommage, mais rien que le dommage), ni más ni menos (tout le préjudice et rien que le préjudice, pas plus; pas moins ${ }^{38}$ ) que se plasma en el artículo 16 de la Ley 446 de 1998 transcrito en su totalidad en el Código General del Proceso en el artículo 283 inciso final: "En todo proceso jurisdiccional la valoración de daños atenderá los principios de reparación integral y equidad y observará los criterios técnicos actuariales", complementándose en los artículos 2342, 2343 y 2344 del Código Civil.

Ahora bien, ¿Por qué se debe responder cuando se causa un daño? La explicación tradicional del fundamento de la responsabilidad civil, la basan en el principio de justicia que impone la necesidad de restablecer el estado anterior o a la situación más cercana antes de la lesión causada injustamente, "la mira del legislador es la de proteger a la víctima de un hecho dañoso, si el hecho del accidente deja a la víctima en condiciones inferiores a las que tenía antes de ocurrir el accidente, indudablemente hay obligación de indemnizar"39. Indemnizar es volver al otro "indemne" (intacto, íntegro) en lo más cercano posible, o en que "la sanción jurídica de la conducta lesiva responde a una elemental exigencia ética" ${ }^{40}$, afirmaciones todas correctas no pudiéndose discutir su acierto dada su obviedad. "Hay, desde luego, un sinfín de sentencias que proclaman la vigencia del principio de la reparación completa, enlazando con una tradición supercentenaria que siempre ha sostenido que la indemnidad constituye el designio del Derecho de la responsabilidad civil"41.

38. LAMBERT FAIVRE, Yvonne, "L'évolution de la responsabilité civil d'une dette de responsabilité à une créance d'indemnisation", en Revue trimestrielle de Droit Civil, 1987, pp. 1 y ss.

39. TAMAYO JARAMILLO, Javier, Tratado de Responsabilidad Civil, T.I, Legis, 2007, p. 398.

40. DE ÁNGEL YAGUÉS, Ricardo. “Tratado de Responsabilidad Civil”. Editorial Civitas SA, Madrid, 1993, p. 13.

41. PANTOJA, Jorge. Op. cit. Tomo I. p. 308 y 309
Como ya lo expresamos, los bienes o intereses protegidos por el derecho no están tipificados en todos los casos, pues la voluntad del legislador ha sido siempre -según una tradición que se remonta a los orígenes de la codificación- dejar abierta tal posibilidad para que sean los jueces quienes determinen en cada situación concreta qué eventos o consecuencias son dignos de ser considerados como daños resarcibles. Por ello los jueces de la República "detentan un poder discrecional de gran trascendencia, en cuanto a la valoración del merecimiento de tutela del interés vulnerado"42, puesto que el exceso de ritualidad, el formalismo sin sentido y la reverencia irreflexiva hacia las reglas, significa desconocer que entre las tareas más altas que han sido confiadas a un juez, cualquiera sea el fuero en que se desempeñe, está la de juzgar con equidad preservando el principio secular de la reparación integral.

\section{El principio de la congruencia en la responsabilidad civil}

De conformidad con la jurisprudencia vigente sobre el principio de congruencia, la causal se configura en los siguientes casos: a) cuando en la sentencia se decide o concede más allá de lo pedido, o sea ultra petita; b) cuando el fallo recae o decide sobre puntos no sometidos al litigio, es decir, de manera extra petita; c) también se presenta incongruencia cuando se decide con base en 'causa petendi' distinta a la invocada por las partes; y, d) cuando el pacto compromisorio se refiere a controversias que no son transigibles por orden constitucional y legal.

En otros términos, para que la sentencia no sea susceptible de anulación por la causal en mención, debe estar en estrecha identidad y resultar armónica con las pretensiones formuladas en la demanda, los hechos puestos en conocimiento por las partes en las oportunidades que el ordenamiento procesal contempla, y las excepciones que hubieren sido alegadas o resulten probadas; y dentro de los límites previstos celebrado por las partes, en la ley y en la Constitución Política, fuentes estas que otorgan y enmarcan la competencia de los jueces.

No se produce incongruencia porque la sentencia recurrida conceda una cantidad superior a la que se había pedido en la demanda,

42. VISINTINI, Giovanna. Op. cit. p. 101. 
teniendo en cuenta que el suplico de la demanda contiene una serie de peticiones subsidiarias por lo que no se produce la incongruencia o la cantidad -pretensión- que señaló fue solo una pauta o guía susceptible de modificación.

Se infiere que el aludido postulado propugna por asegurar los derechos de defensa y de contradicción en cuanto impide que al convocado a un litigio se le sorprenda por el juzgador con hechos o peticiones no alegadas, respecto de las cuales careció de oportunidad para confutarlas, resultando admisible para su demostración, la confrontación o parangón entre lo resuelto en el fallo, con lo planteado en la respectiva demanda, o con el escrito de excepciones de mérito, o con los hechos demostrativos de alguno de tales medios enervantes que deban ser reconocidas de oficio; resultando eficaces las expresiones "o la que se pruebe", o "la que resultare probada", o "la que se probare en el proceso". En tal sentido la Corte suprema de Justicia en Sala de Casación Civil con ponencia del doctor Luis Alonso Rico Puerta ${ }^{43}$ en sentencia del 7 de diciembre de 2016 hace alusión a que la Corte modificó la doctrina que sobre el particular venía aplicando la Corte suprema de Justicia de la Sala de Casación Civil en sentencia del 15 abril de 2009 se sostuvo:

Al contrario de lo que en el pasado estimó, la Corte considera ahora que en aquellos asuntos en cuya demanda, reforma o sustitución de esta, la parte actora pretenda condenación por una suma explícitamente determinada, pero acompañada de expresiones como las particularizadas arriba, (tales como, "o la que se pruebe", o "la que resultare probada", o "la que se probare en el proceso", o cualquiera otra de similar contenido), que son las palabras con las que de modo usual se formulan o plantean las súplicas que tengan como propósito una condena pecuniaria, ninguno de esos agregados se puede concebir como dependiente o subordinado de la cifra expresada que a su alrededor se hubiere manifestado; todo lo contrario, una cabal comprensión del tema permite admitir que dichos complementos la modifican de tal manera que amplían el espectro dentro del cual el juzgador válidamente puede o debe moverse, hacia arriba o hacia abajo de esa cuantificación, sin caer, desde luego, en una resolución infra petita o plus petita,

43. Nombrado en la Corte desde el mes de abril de 2016 proviniendo de la academia como docente prestigioso de la Universidad de Medellín de la Maestría de Derecho, en donde el autor fue docente en dicha Maestría en 2016. pues en tal supuesto está limitado, eso sí, solo por el importe probado a través de los diversos elementos de convicción incorporados al plenario.

Este es, desde luego, el sentido lógico y coherente de las mencionadas locuciones, en tanto están llamadas a representar el verdadero querer del promotor de la causa judicial cuando las súplicas fueren formuladas de la anotada manera; y es bajo el entendimiento que se viene sustentando como ellas adquieren su verdadera eficacia, su importancia y real concreción, pues, con arreglo a esta nueva posición, si las mismas no aparecen en el escrito contentivo de las pretensiones al juez le estará vedado sobrepasar el monto allí indicado, más si llegaren a ser incluidas este entonces no estará supeditado a la cuantía que le haya sido expresamente demandada, puesto que con el presente cambio tendrá la posibilidad de otorgar una suma superior, en aquellos casos que se lo permita el haz probatorio; expresado de otro modo, las memoradas frases resultarán provechosas bajo la doctrina que ahora se prohija, porque si están incluidas en la súplica respectiva y si el acopio probatorio permite establecerlo, harán posible imponer una cifra mayor de la que en términos numéricos la parte actora haya solicitado ${ }^{44}$.

La excepción consagrada al artículo 305 del Código de Procedimiento Civil y al artículo 281 del Código General del Proceso, normas que prevén el principio de la congruencia, ambos con similar redacción -salvo lo relativo a los asuntos de familia y agrarios y a la oportunidad para alegar hechos sobrevinientes a la demanda-, que prohíbe al juez fallar extra o ultra petita, es decir, por fuera o por más de lo pedido, en la medida en que, si media objeción o si se demuestran perjuicios causados con posterioridad a la demanda, tal limitación desaparece, lo cual supone una alteración sustancial al instituto de la congruencia, pues recuérdese que la posibilidad de fallar por más y aún por fuera de lo pedido sólo se consagró en beneficio del demandado, a quien, tanto el artículo 305 del C.P.C. como el 281 del C.G.P., permiten probar hechos impeditivos, modificativos o extintivos del derecho sustancial sobre el cual verse el litigio, siempre que hubiesen sido alegados a más tardar en el alegato de conclusión o que la ley permita considerarlos de oficio (art. 306 c.P.C. y art. 282 del c.G.P.) y aparezcan debidamente probados en el proceso, regla que supone un mayor equilibrio procesal y un avance en materia de acceso a la administración de justicia.

44. Corte Suprema de Justicia, Sala de Casación Civil, sentencia del 15 de abril de 2009, M.P. César Julio Valencia Copete. 
Por su parte el art. 281 del CGP consagra de entrada, en su primer inciso: "La sentencia deberá estar en consonancia con los hechos y las pretensiones aducidos en la demanda y en las demás oportunidades que este código contempla y con las excepciones que aparezcan probadas y hubieren sido alegadas si así lo exige la ley"; tal vez, en aparente contradicción con su inciso segundo que establece: "No podrá condenarse al demandado por cantidad superior o por objeto distinto del pretendido en la demanda ni por causa diferente a la invocada en esta", y con el inciso tercero "Si lo pedido por el demandante excede de lo probado se le reconocerá solamente lo último", en nuestro criterio, por orden de precedencia para su consideración y aplicación se impone, siendo aplicable el inciso segundo donde los hechos y las pretensiones son claras, que no hay asomo de duda, como es en los títulos ejecutivos en donde la ejecución es única por determinado valor y solo por ese valor; $y$ en su inciso tercero, no hay reparo dado que lo probado es menor, es correcto, aunque no compartimos la sanción, como ya lo expresamos, se debe sancionar no al que pide mucho sino al que ofrece muy poco, como sucede en el ordenamiento francés y la exigencia de la oferta indemnizatoria en España por parte de la compañía aseguradora.

En consecuencia, para poder inferir si existió o no incongruencia entre lo concedido en el fallo y lo solicitado en la demanda, no bastará con examinar las cifras que se hayan reclamado en el libelo, sino que esas cantidades deberán ser analizadas en el contexto íntegro de la pretensión y de conformidad con la verdadera intención que a ella subyace, lo cual se consigue a partir de la dimensión del daño -ni más ni menos- atendiendo al principio de la reparación integral, dado que es el daño el que da inicio a la acción.

\section{Monto de la pretensión es limitado únicamente por lo que llegare a probarse}

Es claro, que el juez puede fallar ultra petita, más allá de lo pedido, limitado a lo que resulte probado. Al abrirse paso este nuevo entendimiento, se le quitan al juez las amarras que lo ataban a la absurda posición de no condenar por encima del importe determinado, ya que si el libelo no albergaba alguna de las citadas expresiones "o lo que resulte probado", bajo esa interpretación a él no le era dable imponer suma superior a la abiertamente indicada en la súplica respectiva, más si las ostentaba, de igual modo se encontraba sujeto al quantum demarcado. En ese orden de ideas, resultaba que con arreglo a tal postura daba igual que esos agregados se insertaran u omitieran, por cuanto en nada afectaba lo uno o lo otro, de nada servían tales complementos $\mathrm{y}$, por tanto, afloraban inútiles, posición que fue superada por la jurisprudencia de antaño. Afortunadamente la Corte Suprema de Justicia fija una nueva posición en sentencia del 15 de abril de 2009, (citada en el numeral anterior).

Por tanto, si al decir del Estatuto Procesal Civil, “[...] La sentencia deberá estar en consonancia...", en particular, con "las pretensiones aducidas en la demanda y en las demás oportunidades..." que dicho código contempla, y si en el acto introductorio la parte demandante deprecó que se ordenara a la demandada a pagar, por concepto de la indemnización de perjuicios, la cantidad de dinero allí dicha en una cifra concreta, o "la suma que se probare", con arreglo a la doctrina que ahora rectifica el juzgador, de hallarse demostrado dentro del proceso por tal concepto una cuantía superior a la que de aquel modo el actor hubiera determinado, tendrá forzosamente que imponer la condena por la suma así probada y no por la cifra exacta fijada, porque, ha de reiterarse, al haberse invocado en la pretensión la condenación a cargo de la opositora por la cantidad precisa aducida o "por la que se probare", él juez no tendrá ninguna restricción legal para disponerla en la extensión real y efectivamente demostrada. Aún de este modo estará pronunciándose dentro de los precisos límites trazados por el mentado precepto normativo; antes bien, si en tal supuesto, esto es, de encontrar evidenciado un quantum mayor del expresamente pedido en el libelo, llegara a reducir la condena al guarismo explicitado en la demanda, incurrirá en un fallo incongruente, por mínima petita, por cuanto en tal hipótesis la definición de la controversia judicial no estará en consonancia con las pretensiones aducidas en la demanda y en las demás oportunidades legalmente previstas.

A su vez, el Consejo de Estado sobre el verdadero alcance del principio de la reparación integral indica que se debe buscar en la posibilidad de que sea de la esencia que el daño se cubra integralmente. Frente a situaciones donde el juez descubra que la intensidad y naturaleza del daño va más allá del petitum, o que no fue pedido separadamente ¿podrá desconocer dicha realidad y condenar solo por lo pedido? La respuesta es negativa. 
Así lo consideró la Sección Tercera del Consejo de Estado en sentencia del 20 de febrero de 2008, al hacer prevalecer el cumplimiento cabal del principio de reparación integral en la cual se declaró solidariamente responsable a la Nación -Ministerio de Defensa, Policía Nacionaly al municipio de Tuluá, Valle del Cauca, por la muerte de dos hermanos, quienes fueron secuestrados el 27 de enero de 1995, cuando se encontraban privados de la libertad, y fueron posteriormente asesinados.

En el fallo en cuestión se condenó a los demandados al pago de perjuicios morales y materiales a favor de los familiares de las víctimas $\mathrm{y}$, adicionalmente, a que realizaran una serie de medidas de carácter simbólico, tales como el solicitar excusas en una ceremonia oficial, la publicación de la sentencia en el comando de la policía donde ocurrieron los hechos y la implementación de programas de promoción y respeto a los derechos de las personas.

Por lo tanto, es deber del juez, en estos eventos, no solo limitarse a decretar indemnizaciones monetarias -a partir de la aplicación de bases y criterios actuariales, sino que, su obligación, es integrar las medidas con que cuenta a partir del ordenamiento jurídico interno en su plenitud, como del internacional, con miras a que el restablecimiento derivado de una vulneración a los derechos humanos sea materializado ${ }^{45}$.

En la misma sentencia se deja en claro que no se vulneran los principios de jurisdicción rogada y de congruencia, toda vez que por la naturaleza de la violación el ordenamiento jurídico interno debe ceder frente al internacional, lo que implica adoptar las medidas necesarias prescritas por este último. Allí se precisó:

De otra parte, las medidas que puede adoptar el juez, dirigidas a la reivindicación de los derechos humanos transgredidos en un determinado caso, no desconocen la garantía fundamental de la no reformatio in pejus (relacionado íntimamente con el de congruencia), en tanto no suponen la modificación o el desconocimiento de los límites trazados por la causa petendi de la demanda, sino

45. C. de Estado, Sala de lo Contencioso Administrativo, Sección Tercera, sentencia del 20 de febrero de 2008, rad. 16.996, C.P. Enrique Gil Botero. que dichas medidas conmemorativas, simbólicas, o de no repetición de la conducta, suponen una labor pedagógica e instructiva encaminada a sensibilizar a las entidades públicas y a toda la población, acerca de la importancia del respeto de las garantías fundamentales del individuo ${ }^{46}$.

El Consejo de Estado ha delimitado el principio de reparación integral, así como su contenido y alcance frente a otros principios de índole procesal, en los siguientes términos:

En todo proceso en el que se juzgue la responsabilidad patrimonial del Estado, será posible deprecar medidas de reparación integral, con miras a que se restablezca el statu quo preexistente a la producción del daño.

En consecuencia, siempre será posible que en las demandas de reparación directa los demandantes formulen pretensiones dirigidas o encaminadas a la reparación in integrum del perjuicio, incluso reparaciones in natura. No obstante, en estos supuestos, el juez estará siempre vinculado por el principio de congruencia procesal y de la no reformatio in pejus ${ }^{\mathbf{4 7}}$.

El anterior ejemplo, así como otras jurisprudencias del Consejo de Estado, muestran una fuerte dinámica de innovación en materia de indemnizaciones y dan cuenta de un panorama auspicioso en el desarrollo y aplicación del principio de reparación integral. Sin embargo, no puede olvidarse, en ningún momento, que el núcleo central del régimen de responsabilidad estatal, establecido por la Constitución Política de 1991, en su artículo 90, son las víctimas de los daños antijurídicos y que su resarcimiento debe guiarse, siempre, por los principios de la justicia material y de equidad.

En aplicación del artículo 16 de la Ley 446 de 1998 que establece el principio de reparación integral la jurisprudencia ha dado aplicación al reconocimiento de perjuicios cuando a pesar de no haberse solicitado expresamente en la demanda, de su contenido se infiere tal solicitud y además se encuentre debidamente probado, en especial al daño

46.Ibídem.

47. Consejo de Estado, Sección Tercera, sentencia del 26 de marzo de 2009, exp. 17994. Ver de igual manera: sentencias del 20 de febrero de 2008, exp. 16996 y del 19 de agosto de 2009, exp. 18364 
a la vida de relación o alteraciones a las condiciones de existencia o anteriormente daño fisiológico, en relación con el reconocimiento oficioso de este tipo de perjuicios ${ }^{48}$, el Consejo de Estado precisó:

Si bien es cierto que la reparación de este perjuicio no fue solicitada expresamente en la demanda, la Sala reitera lo que ha afirmado en decisiones anteriores en el sentido de que el perjuicio fisiológico -hoy denominado daño a la vida de relación ${ }^{49}$ o alteración de las condiciones de existencia-, debe ser indemnizado cuando el mismo se encuentra debidamente acreditado, aunque no haya sido pedido en la demanda ${ }^{50}$.

En fallo del 19 de octubre de 2011 expresa:

La Sala en aplicación del principio de reparación integral, y a lo consagrado en el artículo 16 de la Ley 446 de 1998, ordenará unas medidas de satisfacción, teniendo en cuenta que debe ceder el fundamento procesal del principio de congruencia ante la primacía del principio sustancial de la 'restitutio in integrum', máxime cuando existe la vulneración a un derecho humano ${ }^{51}$.

Este concepto de fallo más allá de lo pedido (ultra petita), es diferente de que alguna materia quedó sin resolución (citra petita), o porque la sentencia se remontó a aspectos ajenos al debate (extra petita), cada uno de ellos tiene sus connotaciones específicas.

\section{El destinatario de las sanciones debe ser un fondo para la indemnización de víctimas}

El beneficiario del pago del valor de la sanción deja de ser la contraparte y pasa a ser del Consejo Superior de la Judicatura, Dirección Ejecutiva de Administración Judicial o quien haga sus veces.

48. Consejo de Estado, Sala de lo Contencioso Administrativo, Sección Tercera, sentencia de 10 de agosto de 2000, exp. 12718.

49. Consejo de Estado, sentencia del 19 de julio de 2000, exp. 11.842.

50. Al respecto pueden consultarse sentencias del 18 de febrero de 1999, exp. 12.210; del 3 de mayo de 1999, exp. 11.169 y del 2 de marzo de 2000, exp. 11.250 del Consejo de Estado.

51. Consejo de Estado, Sala Contencioso Administrativa, Sección Tercera, C.P. Jaime Orlando Santofimio Gamboa, sentencia del 19 de octubre de 2011, rad. 68001-23-15-000-1999-00606-01 (20861).
Consideramos que lo correcto, según el derecho comparado, en especial Francia y España, es que esa sanción vaya a un fondo para el pago de víctimas cuando su causante sea un insolvente y sin seguro alguno, o cuando no se pudo determinar un responsable civil, ya sea un tercero o una aseguradora; me refiero exclusivamente a las víctimas de los delitos culposos ya sea por lesiones personales o muerte, generados por un accidente de tránsito o por responsabilidad médica $^{52}$ en general, en las cuales desde el primer día del hecho dañoso el monto indemnizatorio genera intereses, y si su pago es obligación de una entidad de seguros, a partir del primer mes, o sea después de los 30 días de no efectuado su pago. Estos intereses son moratorios o sea a la una y media veces de la tasa de interés corriente respecto de las víctimas y/o beneficiarios; ilustro lo anterior con un análisis del libro Derecho de Daños, en el cual se dijo:

Además de la función indemnizatoria el nuevo derecho de daños tiende no sólo a reparar los daños ya ocurridos, sino a prevenir los futuros, siendo indudablemente preferible evitarlos que repararlos, la participación del Estado es muy importante; sólo los instrumentos que suprimen las fuentes de peligro, o de daño, resultan idóneos para satisfacer globalmente a los grupos sociales que en estos casos se encuentran interesados en forma colectiva; pretendiendo por la socialización del riesgo con políticas de aseguramiento globales y la conformación de fondos que garanticen la reparación de las víctimas sino plena por lo menos parcialmente; junto a la sanción penal debe ir necesariamente la respectiva indemnización. 'Estaba bailando y lo último que recuerdo es que un tipo empezó a disparar al aire, muy borracho, para celebrar la Navidad -narra John-, quien luego de tres años todavía tiene en su cuerpo la bala que lo dejó cuadripléjico. Me desperté en la camilla de un hospital y no podía moverme. Me dijeron que habían pasado tres días y que había quedado invalido'. Dice el joven de menos de 20 años de edad, deportista, quien había ganado tres campeonatos de microfútbol. La persona que festejó de esta manera, cuyo resultado no se lo representó ni tuvo intención de causar daño, es condenado a 11 años de cárcel, condena que es ratificada por la Corte Suprema de Justicia en el año 2010.

52. PANTOJA BRAVO, Jorge. El Daño a la Salud, Leyer, 2016 
En el 2008 el juez de primera instancia le impuso una condena de 20 años de prisión por el delito de tentativa de homicidio agravado. Los testimonios de varios asistentes a la fiesta -que afirmaron que el hombre intentó escapar después del incidentefueron claves durante el juicio. Sin embargo, la decisión del Juzgado 32 penal del circuito fue apelada y llegó al Tribunal Superior de Bogotá, que cambió el delito a tentativa de homicidio simple. La pena pasó de 20 a 11 años. En un nuevo intento por tumbar la condena, el implicado interpuso un recurso de casación ante la Corte Suprema de Justicia, argumentando que los testigos en su contra eran poco confiables, pues habían consumido licor esa noche de Navidad. La Corte desechó el recurso y dejó en firme la condena de 11 años de prisión, "(el implicado) plantea su propia valoración de las pruebas (...) No expresa argumento alguno que haga evidente cuál fue el error cometido por el Tribunal (...) Es una demanda carente de los mínimos requisitos para la impugnación", consideró la Corte ${ }^{53}$.

Desde el Derecho de Daños, el Estado debe ir más allá de la sanción penal, el satisfacer una indemnización, inicialmente por el implicado que de tener medios económicos lo hará, pero en los casos de balas pérdidas cuando no se encuentra al causante, que de ser un agente del Estado se ejercita la acción directa pero si es una persona del común, el Estado debería responder por medio de un fondo, similar por ejemplo a cuando el responsable es un "vehículo fantasma". Con mayor razón si el Estado condena a una persona, y esta resulta ser insolvente, debe indemnizarse al afectado por cualquier medio, la sola sanción social es insuficiente.

De qué le vale al joven cuadripléjico del caso mencionado que la sanción sea de 11 años o de 20 años, o más años o menos años, esto no cambia su situación en absoluto. Para el joven es insuficiente. En algo mitigara su situación si la dignísima alta Corte, hubiese condenado a un ente oficial (llámese alcaldía, gobernación, policía o cualquier otro) a sufragar un pensión vitalicia, por lo menos, de un (1) salario mínimo legal mensual; para remediar esta situación es que se hace necesario la creación de un fondo para las víctimas como en el caso relatado.

53. PANTOJA BRAVO, Jorge. Derecho de Daños, Tomo I, en el Capítulo I "De la responsabilidad clásica al Derecho de Daños", Leyer, 2015, p. 15 y 16
Las sanciones penales tienen una función esencialmente punitiva y represiva, el fundamento de tal autoridad, como lo precisa la doctrina 'reside en un motivo de orden público sumamente simple. Los tribunales represivos, cuando resuelven la acción pública, fallan dentro de un interés social; no juzgan entre dos partes determinadas, sino entre una parte y la sociedad entera"54. Lo que deciden para fallar sobre la acción pública debe, pues, imponerse a todos. A su vez la responsabilidad civil intenta asegurar a las víctimas la reparación de los daños privados que le han sido causados, tratando de poner las cosas en el estado en que se encontraban antes del daño y reestablecer el equilibrio que ha desaparecido entre los miembros del grupo. Por estas razones, la sanción de la responsabilidad civil es, en principio, indemnizatoria y no represiva.

\section{Prueba del perjuicio patrimonial y su cuantía procesalmente son diferentes}

Hay que puntualizar que, desde el punto de vista procesal, una cosa es la prueba del perjuicio patrimonial, en sí mismo considerado, y otra la de su cuantía.

Acreditar lo primero, es comprobar el "detrimento, menoscabo o deterioro" económico que sobrevino a quien pretende el respectivo resarcimiento, es decir, que su patrimonio tuvo una "pérdida", como quiera que se presentó una disminución en sus activos patrimoniales o debió hacer erogaciones o adquirir pasivos para contrarrestar el hecho dañoso o sus efectos (daño emergente) o que a él dejó de reportarse una "ganancia o provecho" que, de manera cierta, esperaba (lucro cesante), o con algunas probabilidades de lograrlo (pérdida de oportunidad).

Comprobar lo segundo, el quantum, requiere indefectiblemente que previamente se haya establecido el perjuicio, propiamente dicho, por lo que comporta establecer en cifras concretas su dimensión económica, esto es, determinar a cuánto trascendió la pérdida o erogación que debió realizar el damnificado o concretar la cuantía de la ganancia o provecho que dejó de ingresar a su patrimonio.

54. Mazeaud, Mazeaudy Tunc. Op. Cit. p. 354. 
Como se dijo, una cosa es la existencia o no del perjuicio, y otra la cuantía del mismo; en efecto, lo importante para que el daño sea considerado como cierto no es que se pueda acreditar su cuantía sino que se pueda acreditar su existencia. Para que el perjuicio se considere como existente, debe probarse su certeza. Por tanto, los daños patrimoniales y extrapatrimoniales cuya existencia se acrediten debidamente dentro del proceso, serán considerados como ciertos, sin importar que su cuantía no esté acreditada o determinada para ese momento. Por tal razón debe enfatizarse la autonomía e independencia de cada uno de esos laboríos, pese a su estrecha relación, y que, por consiguiente, no debe confundírseles como si se tratara de una misma actividad y, menos aún, sujetarse la demostración del daño a la de su quantum, pues, como se aprecia, la regla que al respecto pudiera elaborarse sería exactamente la contraria, es decir, que la comprobación de la cuantía del perjuicio depende de la previa y suficiente constatación de la lesión patrimonial sufrida por el afectado.

Ello explica que en el plano procesal el incumplimiento de uno $\mathrm{u}$ otro deber provoquen efectos diversos. Mientras que la falta de acreditación del daño conduciría a colegir la insatisfacción del más importante elemento estructural de la responsabilidad civil, contractual y extracontractual, y, por ende, el fracaso de la correlativa acción judicial, la insatisfacción del segundo impone al juez decretar "de oficio, por una vez, las pruebas que estime necesarias" para condenar "por cantidad y valor determinados". Entre otros supuestos, al pago de los "perjuicios" reclamados debidamente discriminados (art. 206 CGP), en ausencia de una valor determinado, el juez puede acudir al principio de equidad incorporado normativamente en la Ley 446 de 1998 en su artículo 16,

es posible acudir a la equidad para determinar el monto del daño, en aquellos casos límite, en que, habiéndose acreditado el perjuicio patrimonial, la determinación de su cuantía se torna extremadamente difícil, no obstante el cumplimiento de las cargas probatorias por la parte demandante ${ }^{55}$

desde luego que la falta de la prueba del quantum de ese perjuicio corresponde suplirla a los

55. Corte Suprema de Justicia, Sala de Casación Civil, sentencia del 28 de febrero de 2013, M.P. Arturo Solarte Rodríguez, exp. 11001-3103-004-2002-01011-01. juzgadores de instancia, cumpliendo con el deber de decretar pruebas de oficio, tal como lo ordena el artículo 307 del Código de Procedimiento Civil, precepto este que vedó, como principio general, las condenas en abstracto o in genere y, por ende, la absolución por la falta de determinación de una condena concreta" ${ }^{56}$.

\section{Caso: Aplica lo estimado de la pretensión y no el valor probado ostensiblemente mayor (más de mil millones de pesos)}

El demandante estima su pretensión en 250 millones de pesos y el dictamen de parte y de oficio los fijan en \$1.202'552.387 y en \$1.397'587.126 respectivamente, sentenciando por el valor estimado, con una diferencia promedio en más de mil millones de pesos.

El Instituto Nacional de Educación y Superación Politécnico INDES, instauró acción de tutela con el propósito de obtener el amparo de los derechos fundamentales al debido proceso y a la "tutela efectiva de la justicia", que considera vulnerados por las autoridades accionadas (Tribunal de Arbitramento y Sala Civil de la Corte Suprema Justicia). Argumentó que convocó a Tribunal de Arbitramento a la Corporación Universitaria REMINGTON, debido a la controversia surgida por el incumplimiento del contrato cuyo objeto es la oferta y promoción de los programas académicos de la convocada en los departamentos de Sucre y Córdoba, con excepción de Montería. Adujo que, mediante fallo del 29 de mayo de 2013, que fue adicionado el 12 de junio siguiente, mediante la cual el Tribunal de Arbitramento de Sincelejo declara que la convocada incumplió las obligaciones del contrato suscrito entre las partes, pero al cuantificar los daños dispuso reconocer únicamente la suma de $\$ 250 \prime 000.000$, a pesar de que en la demanda se solicitó el pago de la suma señalada o "el valor que se demuestre en el proceso".

En el trámite arbitral se practicaron dos dictámenes periciales, el primero por solicitud de ambas partes y el segundo ordenado por el Tribunal de Arbitramento, los cuales cuantificaron los perjuicios en las cantidades

56. Corte Suprema de Justicia, Sala de Casación Civil, sentencia del 3 de marzo de 2004, exp. C-7623. 
de $\$ 1.202^{\prime} 552.387,45$ y en $\$ 1.397^{\prime} 587.126,51$, respectivamente, pero este Tribunal tomó la cifra estimada por el actor en la demanda o sea la suma de $\$ 250$ '000.000,oo, "por considerar (...) que sus facultades no comportan las de condenar por encima de lo pedido por el demandante", de conformidad con lo establecido en el artículo 305 del Código de Procedimiento Civil.

Argumentó que el citado Tribunal desconoció la salvedad de su pretensión, pues si bien se pidió una condena por $\$ 250^{\prime} 000.000$,oo también dijo “o por el valor que se demuestre en el proceso", y se probó en forma incuestionable que los perjuicios sufridos fueron por una suma mayor, como lo reconoció el mismo fallador. Añadió que el Tribunal de Arbitramento incurrió en yerro al dejar de valorar una prueba practicada en debida forma, se refiere a los dos dictámenes mencionados.

Presentó recurso de anulación con fundamento

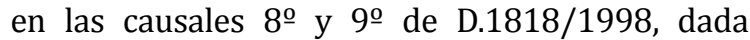
la incongruencia existente entre lo pedido y lo reconocido y porque el laudo dejó de decidir sobre un punto sometido a su consideración. Empero, el Tribunal Superior de Sincelejo lo declaró infundado al considerar que no estaban dados los supuestos fácticos que encuadraba en cada una de las causales invocadas, desconociendo el tenor literal de la demanda que originó el litigio y, por ende, que el Tribunal de Arbitramento no falló sobre "el valor que se demuestre en el proceso", manifestando el Tribunal de Arbitramento que analizó la jurisprudencia de la Sala de Casación Civil, que le da la posibilidad a los jueces de imponer condenas, siempre que estén demostradas, por cuantías superiores a la determinada por el actor, cuando a la cifra exacta se haya acompañado la expresión "o por la que se probare". Sin embargo, con argumentos razonados se apartó de ella.

El juez de tutela (Corte suprema de Justicia, Sala de Casación Laboral) expresa:

No sobra señalar, que el Tribunal de Arbitramento al fijar el valor de la indemnización, en la suma estimada por el actor en la demanda al presentar el juramento estimatorio de perjuicios, se avino a lo señalado en el CGP art. 206, que prohíbe al juzgador 'reconocer suma superior a la indicada en el juramento estimatorio, salvo los perjuicios que se causen con posterioridad a la presentación de la demanda o cuando la parte contraria lo objete. Serán ineficaces de pleno derecho todas las expresiones que pretendan desvirtuar o dejar sin efecto la condición de suma máxima pretendida en relación con la suma indicada en el juramento'. Situación que constituye una razón demás para revocar el fallo impugnado, pues no era viable que se tuviera en cuenta la expresión 'o el valor que se demuestre en el proceso', como es la pretensión del accionante ${ }^{57}$.

Resolviendo en sentencia del 30 de julio de 2014 negar la tutela de los derechos invocados por el Instituto Nacional de Educación y Superación Politécnico INDES, es decir, dio prioridad al valor de las pretensiones estimados mediante juramento estimatorio frente a la suma demostrada y probada por dos dictámenes, uno de parte que el CGP privilegia y otro de oficio. Los dos señalan una diferencia promedio de más de mil millones de pesos del año 2013, aseverando que no era viable que se tuviera en cuenta la expresión 'o el valor que se demuestre en el proceso' que fue el imperio del artículo 305 del Código de Procedimiento Civil que ahora deroga el Código General del Proceso, enviando al barranco lo probado. En el presente caso el dictamen de parte que este mismo código privilegia y lo entroniza como prueba. Diríamos además que es una prueba calificada que ha superado el interrogatorio de la contraparte y del juez, además el mismo juez lo ha corroborado por su análisis integral con las demás pruebas, so pretexto de una interpretación insular del inciso segundo del artículo 281 desdeñando el inciso primero de este mismo artículo, que por supuesto tiene precedencia en su consideración y aplicación, está antes, de primero. Su texto: "La sentencia deberá estar en consonancia con los hechos", que en criterio del investigador es la medida de daño que se ha logrado probar dentro del proceso, imperante desde los comienzos del derecho, es más es el derecho en sí.

Volviendo al caso que nos ocupa, el tribunal de arbitramento, para el efecto juez, ante la diferencia significativa entre el juramento estimando por 250 millones de pesos y el monto del dictamen de parte dictaminados en \$1.202'552.387 resultando una diferencia de cerca de mil millones de pesos, por lo cual el juez (tribunal de arbitramento) acude al mismo artículo 206 que reglamenta el Juramento Estimatorio, aplicando el inciso tercero:

57. C. Suprema de Justicia, Sala de Casación Laboral, M.P., Carlos Ernesto Molina Monsalve, sentencia del 30 de julio de 2014, STL10760-2014, radicación 55051 
"Aun cuando no se presente objeción de parte, si el juez advierte que la estimación es notoriamente injusta, ilegal o sospeche que haya fraude, colusión o cualquier otra situación similar, deberá decretar de oficio las pruebas que considere necesarias para tasar el valor pretendido". (resaltado fuera de texto)

Dado que el Juez advierte que la estimación es notoriamente injusta (y por lo tanto ilegal) decreta de oficio un dictamen judicial para tasar el valor pretendido, como lo estipula el CGP, emitido por un experto (perito) de la lista de auxiliares escogido por el mismo juez, siendo imparcial, capaz y garante de credibilidad total, puesto que es el juez que lo elije y es ante él que presenta sus conclusiones. Este tasa la indemnización en \$1.397'587.126, suma que comparada con el valor pretendido de 250 millones de pesos resulta en una diferencia de más -no cercanade mil millones de pesos (exactamente de \$1.147'587.126), que avala el dictamen de parte y lo corrobora las demás pruebas del proceso. El juez de manera prevalida se sujeta ciegamente a lo tasado en el juramento estimatorio sin mirar, en absoluto, la prueba ordenada por él mismo, la cual cumple con todos los requisitos, no se observa impedimento alguno o que el perito era incapaz o recusado por alguna razón. En nuestro criterio de esta investigación lo tasado bajo juramento es válido mientras no se objete. De objetarse da vía al fallo ultra petita (art. 206 del CGP) siempre que el daño probado su monto sea mayor; igual consideración si el juez advierte que la estimación es notoriamente injusta, como en el presente caso, que dicha codificación lo amplia a si es ilegal o sospeche que haya fraude, colusión o cualquier otra situación similar, entonces el mismo juez "deberá decretar de oficio las pruebas que considere necesarias para tasar el valor pretendido", su finalidad es clara e inequívoca para tasar el valor pretendido, deviniendo inaplicable la pretensión estimado bajo juramento.

\section{Caso: Niega el Lucro Cesante e impone sanción económica del Juramento Estimatorio (Art. 206 del CGP)}

La demandante Ferroequipos mediante contrato de compraventa suscrito el 27 de febrero de 2004 compró 34 (treinta y cuatro) montacargas y pagó el día 1 o de marzo de 2004 a la demandada Bavaria S.A., quien se ha abstenido de cumplir con la entrega real y material de la totalidad de los mencionados montacargas, así como con la totalidad de los documentos y títulos de propiedad necesarios para su uso y disposición. A pesar de los varios requerimientos hechos a la demandada se ha abstenido de entregar tanto la documentación para su registro, títulos de propiedad y documentos de importación de la totalidad de los 34 montacargas importados como tampoco la entrega real y material de 18 de los equipos pagados mencionados. Todo lo anterior ha imposibilitado el uso, usufructo, tránsito y disposición en el territorio nacional de los equipos comprados a Bavaria S.A.

Se presentó una demanda ante el Tribunal de Arbitramento de Bogotá para que se declare resuelto el contrato de compraventa suscrito el 27 de febrero de 2004 con Bavaria S.A., y se condene a esta última a pagar a favor de Ferroequipos la suma de novecientos cincuenta y cinco millones quinientos sesenta y cuatro mil seiscientos treinta y tres pesos $\left(\$ 955^{\prime} 564.633,00\right) \mathrm{M} /$ cte., por concepto de daño emergente, y la suma de cinco mil ochocientos ochenta y seis millones quinientos cincuenta y siete mil novecientos setenta y seis pesos $\left(\$ 5.886^{\prime} 557.976,00\right) \mathrm{M} /$ cte., por concepto de lucro cesante.

El Tribunal de Arbitramento profiere laudo el 8 de noviembre de 2013 que declara la resolución del contrato de compraventa y niega el lucro cesante al declarar próspera la excepción llamada "objeción a la estimación jurada de los perjuicios", ordenando las restituciones mutuas y reconociendo el daño emergente al ordenar a la sociedad Bavaria S.A. a pagar a la sociedad Ferroequipos, a título de indemnización compensatoria por concepto de daño emergente, la suma actualizada de cuatrocientos cuarenta y cuatro millones noventa y ocho mil ochocientos veintisiete pesos (\$444'098.827) moneda corriente, que Ferroequipos pagó como precio de treinta (30) montacargas según el Contrato de Arrendamiento de Bienes Muebles y Prestación de Servicios celebrado entre Ferroequipos y Bavaria S.A. el 27 de febrero de 2004 -se refiere al contrato de compraventa-. Denegó el lucro cesante, condenando a Ferroequipos a pagar Bavaria S.A., la suma de doscientos noventa y cinco millones setecientos ocho mil pesos ( $\left.\$ 295^{\prime} 708.000\right)$ moneda corriente por concepto de costas del proceso.

Recurso de anulación. Contra el anterior laudo ambas partes presentan recurso de anulación 
ante la Sala Civil del Tribunal Superior del Distrito Judicial de Bogotá, que mediante providencia del 4 de junio de 2014, declaró fundado el cargo formulado por Bavaria S.A. respecto “(...) a la falta de congruencia (...)", imponiéndole a Ferroequipos la sanción prevista en el inciso $4^{\circ}$ del artículo 206 del Código General del Proceso sobre el Juramento Estimatorio. Apelación que el Tribunal Superior de Bogotá adiciona la sanción prevista en el inciso 4ํㅡㅁ del artículo 206 del Código General del Proceso sobre el Juramento Estimatorio al declarar fundado el cargo formulado de la contraparte, Bavaria, respecto "(...) a la falta de congruencia (...)", en este orden de ideas, el juez de primera instancia (el Tribunal de Arbitramento) debería haber aplicado dicha sanción, dado que posteriormente vía tutela y la impugnación a la misma confirman la decisión del laudo.

Es comprensible que en las restituciones mutuas son un conflicto difícil de solucionar en razón a que el bien a devolver con sus mejoras, utilidades y frutos, y su contraparte en dinero a reintegrar con su actualización y/o intereses, de encontrar un balance a más de las pretensiones que puede ser muy diversas, entre ellas quedarse con el bien o recibir determinadas cantidades de dinero, que en el proceso pueden tomar un curso imprevisto que conlleven a que se nieguen algunos rubros indemnizatorios o que en la demanda determinada circunstancia no se tuviera en cuenta, aplicando la sanción del juramento estimatorio como sucedió en el laudo arbitral en comento:

[...] Eran montacargas viejos ya obsoletos, terminado el contrato de arrendamiento algunos podrían ser aun servibles, aunque más obsoletos y otros podrían ser ya inservibles y tampoco se sabría qué vida útil podría tener cada uno de ellos, obviamente ese escenario no planteado por la convocante hace que en este proceso las estimaciones sobre lucro cesante hasta el año 2015 resultan hipotéticas y especulativas, lo cual se opone a que sean indemnizados ${ }^{58}$. (negrillas fuera de texto)

Sea necesario hacer un paréntesis, la empresa Ferroequipos recibe de Bavaria la suma de \$444'098.827,0o (valor actualizado a la fecha de la sentencia) que pagó por la compra de los montacargas, pero a su vez, debe pagar a Bavaria

58. Laudo arbitral, Ferroequipos Yale Ltda., contra Bavaria S.A. Bogotá, D. C., 8 de noviembre de 2013, Árbitros: Carlos Ignacio Jaramillo Jaramillo y Marcela Castro de Cifuentes el valor de $\$ 295^{\prime} 708.000$,oo por concepto de costas del proceso, o sea que realmente recibe $\$ 148^{\prime} 390.827$, oo, es decir recibe menos del $35 \%$ del valor pagado a Bavaria, faltando pagar la sanción por Juramento Estimatorio que la segunda instancia le impone, que si se toma el 10 o el $5 \%$ absorbe este valor residual y queda debiendo, hasta aquí el paréntesis

Debido a lo anterior Ferroequipos instaura una tutela censurando la decisión adoptada por los árbitros, de denegar sin justificación sus exigencias resarcitorias, y al Tribunal Superior de Bogotá por imponerle la citada multa "a pesar de que ese punto había sido fallado y por ende emitir pronunciamiento sobre un asunto frente al cual no eran competentes". Solicita el amparo de los derechos fundamentales al debido proceso y acceso a la administración de justicia, y como consecuencia dejar sin efecto la sentencia proferida por el Tribunal Superior, y en su lugar se corrija el Laudo Arbitral declarando impróspera la objeción a la estimación jurada de los perjuicios y se condene al pago de la indemnización reclamada; a su turno la Corte Suprema de Justicia en Sala de Casación Civil profiere sentencia del 11 de diciembre de 2014 negando el amparo constitucional pretendido, toda vez que en las providencias censuradas no se advierte un proceder arbitrario o caprichoso por parte de los querellados. Por lo cual Ferroequipos, impugna este fallo proferido el 11 de diciembre de 2014 por la Sala de Casación Civil. La Sala de Casación Laboral mediante sentencia del 4 de marzo de 2015 confirma el fallo impugnado, ambas de la Corte Suprema de Justicia.

Nos llama la atención que Tribunal de Arbitramento declara resuelto el contrato de compraventa por el incumplimiento de Bavaria S.A. y ordenó las restituciones mutuas; no alcanzamos a vislumbrar los efectos del incumplimiento de Bavaria S.A., que deberían reflejarse en algunos perjuicios de daño emergente y lucro cesante, por la sencilla razón que tuvo la maquinaria por algún tiempo, en nuestro concepto que lo utilice o no debe generar un pago dado que es un bien productivo, se trata de maquinaria que si el incumplido -el comprador- la recibió era para utilizarla (sino para qué la compra). Lo anterior salvo lo que exprese el laudo.

De otra parte, consideramos que el Tribunal Superior del Distrito Judicial, como juez de segunda instancia, comete un yerro al imponer la sanción 
económica del inciso 4 del Art. 206 del CGP a Ferroequipos dado que el Tribunal de Arbitramento de Bogotá declara la resolución del contrato de compraventa por incumplimiento de Bavaria, sin ninguna inconformidad o cuestionamiento de esta decisión, siendo esta su pretensión principal y única; de no darse esta situación no se genera ninguna otra pretensión. Es decir, habría cumplimiento de Bavaria sin tener sentido instaurar la demanda de perjuicios que serían inexistentes; sin embargo, el Tribunal Superior para imponer dicha sanción argumenta que a Bavaria le prospera la excepción llamada "objeción a la estimación jurada de los perjuicios", le prospera pero de manera parcial dado que el daño emergente sobre el pago de las montacargas se aceptó por el Tribunal de Arbitramento el cual ordena restituirlos actualizados; estamos convencidos de que sobre excepciones que prosperan parcialmente que se derivan de una principal, que si prosperó, dicha sanción deviene inaplicable. Esperamos que la jurisprudencia venidera así lo considere.

\section{CONCLUSIONES}

En consecuencia con la doctrina, jurisprudencia y normas del Código de Procedimiento Civil , del Código del Proceso, y los pronunciamientos de la Corte analizadas, forzoso es concluir que el monto de la pretensión es limitado únicamente por lo que llegare a probarse, siendo viable y legal que el juez sobre la cantidad pedida en las pretensiones puede condenar por una suma mayor de hallarse demostrado dentro del proceso por tal concepto una cuantía superior a la que de aquel modo el actor hubiera determinado. Caso con- trario, esto es, si se llegara a reducir la condena al guarismo explicitado en la demanda, incurrirá en un fallo incongruente por mínima petita, con el agravante de legitimar la indemnización parcial a la víctima debido a la instauración de demandas reducidas por temor a la sanción al sobrepasar en el $50 \%$ de lo probado en el proceso y en el evento que los daños se declaren no probados.

Tiene un rol importante el abogado litigante al tener que esgrimir los argumentos e interpretaciones de las normas expuestas de manera integral en favor de las víctimas y/o beneficiarios, como lo interpretó en su momento la Corte suprema de Justicia de la Sala de Casación Civil en sentencia del 15 abril de 2009 , sosteniendo que la expresiones "o la que se pruebe", o "la que resultare probada", o "la que se probare en el proceso", o cualquiera otra de similar contenido, tienen eficacia superando la retrograda interpretación que el demandante solo quería lo pedido, siendo a todas luces injusto cuando el daño es mayor. La sentencia en comento concreta: "expresado de otro modo, las memoradas frases resultarán provechosas bajo la doctrina que ahora se prohija, porque si están incluidas en la súplica respectiva y si el acopio probativo permite establecerlo, harán posible imponer una cifra mayor de la que en términos numéricos la parte actora haya solicitado".

En las condiciones expuestas la afirmación: "el monto estimado por los actores no marca el límite de la pretensión sino la medida del daño", adquiere validez jurídica y procesal. 


\section{BIBLIOGRAFÍA}

- ALESSANDRI RODRÍGUEZ, Arturo, De la responsabilidad extracontractual en el derecho civil, Santiago de Chile: Imprenta Universal, 1981

- Cámara de Comercio de Bogotá. Tribunal de Arbitramento profiere laudo el 8 de noviembre de 2013 Ferroequipos Yale Ltda., contra Bavaria S.A. Árbitros: Carlos Ignacio Jaramillo Jaramillo y Marcela Castro de Cifuentes

- CHARTIER, Ives, La reparation du prejudice, París, Dalloz, 1983, № 124.

- Corte Constitucional, sentencia C-157 de 21 de marzo de 2013, exp. D-9263, y sentencia C-332 de 05 de junio de 2013, exp. D-9514, ambas con ponencia del doctor Mauricio González Cuervo

- Consejo de Estado, Sala Contencioso Administrativa, Sección Tercera, C.P. Jaime Orlando Santofimio Gamboa, sentencia del 19 de octubre de 2011, rad. 68001-23-15000-1999-00606-01 (20861).

- Consejo de Estado, Sala de lo Contencioso Administrativo, Sección Tercera, sentencia del 20 de febrero de 2008, rad. 16.996, C.P. Enrique Gil Botero

- Consejo de Estado, Sala de lo Contencioso Administrativo, Sección Tercera, sentencia de 10 de agosto de 2000, exp. 12718.

- Consejo de Estado, Sección Tercera, sentencia del 26 de marzo de 2009, exp. 17994, sentencias del 20 de febrero de 2008, exp. 16996 y del 19 de agosto de 2009, exp. 18364

- Consejo de Estado, sentencia del 19 de julio de 2000, exp. 11.842. sentencias del 18 de febrero de 1999, exp. 12.210; del 3 de mayo de 1999, exp. 11.169 y del 2 de marzo de 2000, exp. 11.250

- Corte Suprema de Justicia, Sala de Casación Civil, sentencia del 15 de abril de 2009, M.P. César Julio Valencia Copete.

- Corte Suprema de Justicia, Sala de Casación Laboral, M.P., Carlos Ernesto Molina Monsalve, sentencia del 30 de julio de 2014,
STL10760-2014, radicación 55051

- Corte Suprema de Justicia, Sala de Casación Civil, sentencia del 28 de febrero de 2013, M.P. Arturo Solarte Rodríguez, exp. 11001-3103-004-2002-01011-01

- Corte Suprema de Justicia, Sala de Casación Civil, sentencia del 3 de marzo de 2004, exp. C-7623

- Corte Suprema de Justicia, Sala de Casación Laboral, M.P., Carlos Ernesto Molina Monsalve, sentencia del 30 de julio de 2014, STL10760-2014, radicación 55051

- Corte suprema de Justicia, Sala de Casación Laboral, M.P., Luis Gabriel Miranda Buelvas, sentencia del 4 de marzo de 2015, STL25412015, radicación 60359

- Corte Suprema de Justicia, Sala de Casación Penal, sentencia del 18 de diciembre de 2012, proceso 05266-31-03-001-200400172-01, M.P. Ariel Salazar Ramírez

- DE ÁNGEL YAGUÉS, Ricardo. "Tratado de Responsabilidad Civil". Editorial Civitas SA, Madrid, 1993

- DE CUPIS, Adriano. El daño, Ed. Bosch; España, 2 a edición, 1975

- DÍEZ PICAZO, Luis y DE LEÓN, Ponce, Derecho de Daños, Madrid, Civitas, S. A, 1999

- GAVIRIA CARDONA, Alejandro, Manual de liquidación de perjuicios patrimoniales, ediciones Anaula, Junio de 2016.

- GIL BOTERO, Enrique. Teoría de responsabilidad extracontractual del Estado, Medellín, Librería Jurídico Sánchez R. Ltda., $2^{\mathrm{a}}$ ed., 2001

- JÍMENEZ GIL, William. Entre reglas y principios. Revista Misión Jurídica, Vol. 1, No. 1, 2008, p.p. 15 -50.

- LA CAPITAL. Millonaria indemnización a una mujer que, tras dar a luz, le amputaron sus miembros. (En línea) Consultado el 01 de diciembre de 2016, En: http:// www.lacapital.com.ar/informaciongral/millonaria-indemnizacion-unamujer-que-dar-luz-le-amputaron-sus- 
miembros-n468880.html

- LAMBERT FAIVRE, Yvonne, “L'évolution de la responsabilité civil d'une dette de responsabilité à une créance d'indemnisation", en Revue trimestrielle de Droit Civil, 1987, pp. 1 y ss; y en "La evolución de la responsabilidad civil; de una deuda de responsabilidad a un crédito de indemnización”, trad. Eliana Núñez, en ALTERINI, Atilio y Roberto LÓPEZ CABANA, Derecho de daños (y otros estudios), Buenos Aires, La Ley, 1992

- MAZEAUD, Henri - León - Jean. Lecciones de derecho civil, La responsabilidad civil. Los cuasicontratos, Buenos Aires, Ediciones Jurídicas Europa-América, Parte segunda, Vol. II., 1960

- MAZEAUD, Henri; MAZEAUD, León, TUNC, André, "Tratado teórico y práctico de la responsabilidad civil", Buenos Aires, EJEA, Argentina, Tomo I, volumen I, 1961

- MEDINA CRESPO, Mariano, Conservación y progreso en el nuevo baremo de tráfico: gozos y sombras por lo que se resarce y deja de resarcir, en HERRADOR
GUARDIA Mariano José. Director, Daño, responsabilidad y seguro, Ed. Francis Lefebvre, 11 de noviembre de 2016

- PANTOJA BRAVO, Jorge. Derecho de Daños, Tomo I, II y III, Leyer, 2015

- PANTOJA BRAVO, Jorge. El Daño a la Salud, Leyer, 2016

- PINZÓN MUÑOZ, Carlos Enrique. "La reparación directa, aspectos procesales y probatorios", 3ra edición, Ibañez, 2016

- PLANIOL, Marcel y RIPERT, Georges. Tratado práctico de derecho civil francés, Tomo VI. Las obligaciones, Primera Parte, Habana, Ed. Cultural La Habana - Traducción española del Dr. Mario Diaz Cruz - Con el Concurso de René Savatier, 1946

- QUINTERO PÉREZ, Magda Isabel, El juramento estimatorio en el Código General del Proceso, Legis on line, publicado el 04 de agosto del 2016

- TAMAYO JARAMILLO, Javier, Tratado de Responsabilidad Civil, T.I, Legis, 2007.

- VISINTINI, Giovanna. ¿Qué es la responsabilidad civil? Bogotá: U. Externado de Colombia. 2015. 